\title{
PENGARUH BUDAYA ORGANISASI, KOMPENSASI, KEPEMIMPINAN, DISIPLIN KERJA DAN MOTIVASI TERHADAP KEPUASAN KERJA DAN DAMPAKNYA PADA PRODUKTIVITAS KARYAWAN (STUDI KASUS PADA PT. PANAIRSAN PRATAMA)
}

\author{
Mohammad Benny Alexandri ${ }^{1}$, Wahid Akbar Basudani ${ }^{2}$ \\ ${ }^{1}$ Universitas Padjadjaran \\ ${ }^{2}$ Sekolah Tinggi Ilmu Ekonomi Indonesia (STIE) \\ bennyalexandri@yahoo.co.id ${ }^{1}$, wahidakbarbasudani@gmail.com²
}

\begin{abstract}
ABSTRAK
Penelitian ini bertujuan untuk mengetahui apakah terdapat pengaruh budaya organisasi, kompensasi, kepemimpinan, disiplin kerja dan motivasi terhadap kepuasan kerja dan dampaknya terhadap produktivitas karyawan PT. Panairsan Pratama. Strategi penelitian yang digunakan adalah strategi asosiatif. Adapun metode penelitian yang digunakan dalam penelitian ini adalah metode survey sampel. Populasi dalam penelitian ini adalah 60 karyawan PT. Panairsan Pratama. Jumlah sampel menggunakan stratified simple random sampling dimana 60 orang karyawan di klasifikasi berdasarkan jabatan sebesar 70\% dari total populasi sehingga diperoleh 42 orang. Perhitungan statistik dimulai dari uji kualitas data (validitas, reliabilitas, dan normalitas). Metode analisis data yang digunakan adalah analisis jalur atau Path Analysis.Hasil penelitian diperoleh nilai koefisien regresi parsial $\mathrm{X}_{1}$ dengan $\mathrm{Y}$ adalah sebesar 0,363 , $\mathrm{X}_{2}$ dengan $\mathrm{Y}$ adalah sebesar 0,188, $\mathrm{X}_{3}$ dengan $\mathrm{Y}$ adalah sebesar $0,347, \mathrm{X}_{4}$ dengan $\mathrm{Y}$ adalah sebesar -0,042, $\mathrm{X}_{5}$ dengan $\mathrm{Y}$ adalah sebesar 0,473. Nilai koefesien regresi berganda antara variabel bebas $X_{1}, X_{2}, X_{3}, X_{4}, X_{5}$ terhadap $\mathrm{Y}$ adalah 0,661. Nilai koefisien regresi parsial $\mathrm{X}_{1}$ dengan $\mathrm{Z}$ adalah sebesar $-0,284, \mathrm{X}_{2}$ dengan $\mathrm{Z}$ adalah sebesar -0,134, $\mathrm{X}_{3}$ dengan $\mathrm{Z}$ adalah sebesar --0,416, $\mathrm{X}_{4}$ dengan $\mathrm{Y}$ adalah sebesar 0,468, $X_{5}$ dengan $Z$ adalah sebesar 0,489 , $Y$ dengan $Z$ sebesar 0,224. Nilai koefesien regresi berganda antara variabel bebas $\mathrm{X}_{1}, \mathrm{X}_{2}, \mathrm{X}_{3}, \mathrm{X}_{4}, \mathrm{X}_{5}$ melalui Y terhadap Z adalah 0,394. Pengujian hipotesis secara simultan dengan $\alpha=0,05$ menunjukan terdapat pengaruh yang positif dan signifikan budaya organisasi, kompensasi, kepemimpinan, disiplin kerja dan motivasi terhadap kepuasan kerja dan dampaknya terhadap produktivitas.
\end{abstract}

Kata Kunci : Budaya Organisasi, Kompensasi, Kepemimpinan, Disiplin Kerja, Motivasi, Kepuasan Kerja, Produktivitas

\begin{abstract}
This study aims to determine whether there is an influence of coorporate culture, compensation, leadership, work discipline and motivation on job satisfaction and its impact on the productivity of employees of PT. Panairsan Pratama. The research strategy used is associative strategy. The research method used in this study is the sample survey method. The population in this study
\end{abstract}


were 60 employees of PT. Panairsan Pratama. The number of samples using stratified simple random sampling where 60 employees in the classification based on the position of $70 \%$ of the total population so that 42 people obtained. The statistical calculation starts from the test of data quality (validity, reliability, and normality). The data analysis method used is path analysis.

The results obtained by partial regression coefficient $X 1$ with $Y$ is $0.363, X 2$ with $Y$ is equal to $0.188, X 3$ with $Y$ is equal to $0.347, X 4$ with $Y$ is equal to $-0.042, X 5$ with $Y$ is 0.473 . The multiple regression coefficient value between the independent variables $X 1, X 2, X 3, X 4, X 5$ to $Y$ is 0.661 . Partial regression coefficient value $X 1$ with $Z$ is equal to $-0.284, X 2$ with $Z$ is equal to $-0.134, X 3$ with $Z$ is equal to -0.416, $X 4$ with $Y$ is $0.468, X 5$ with $Z$ is $0.489, Y$ with $Z$ is 0.224 . Multiple regression coefficients between independent variables $X 1, X 2, X 3, X 4, X 5$ through $Y$ to $Z$ are 0.394. Simultaneous hypothesis testing with $\alpha=0.05$ indicates that there is a positive and significant influence on coorporate culture, compensation, leadership, work discipline and motivation on job satisfaction and its impact on productivity.

\section{Keywords: Coorporate Culture, Compensation, Leadership, Work Discipline Motivation, Job Satisfaction, Productivity}

\section{PENDAHULUAN}

Berbicara jauh mengenai pembangunan infrastuktur di Indonesia, maka tidak akan lepas dari peran Kementrian Pekerjaan Umum dan Perumahan Rakyat (PUPR). Kementrian tersebut memegang peranan utama dalam pembangunan di Indonesia. Kementrian PU ini lah yang memiliki anggaran dalam rangka pembangunan infrastuktur. Dengan anggaran yang mereka miliki, kementrian tersebut mengadakan lelang untuk proyek proyek pembangunan infrastruktur.

Menteri Pekerjaan Umum dan Perumahan Rakyat Basuki Hadimoeljono mengungkapkan banyak proyek konstruksi yang pada saat pelaksanaan pekerjaan mengalami kegagalan, sehingga mengakibatkan tidak tercapainya kualitas hasil pekerjaan, keterlambatan waktu penyelesaian, hingga menelan korban jiwa akibat kecelakaan. Untuk itulah diperlukan dukungan peralatan pengujian sebagai suatu alat yang dapat dijadikan acuan untuk mengukur dan menjamin kualitas suatu konstruksi, karena peralatan pengujian merupakan salah satu mata rantai yang sangat penting guna menjamin mutu/kualitas dan keamanan dari suatu produk konstuksi, baik sebelum maupun sesudah pelaksanaan konstruksi.

PT. Panairsan Pratama adalah salah satu kontraktor Kementrian PUPR yang menjadi pelopor di bidang pengadaan alat uji konstruksi. Salah satu departmen dalam struktur organiasasi Kementrian PUPR yaitu Balai Besar Pembangunan Jalan Negara (BBPJN) yang tersebar di semua provinsi di Indonesia menjadi pelanggan utama dari PT. Panairsan Pratama.

Perusahaan yang sudah menjadi langganan bagi salah satu Kementrian terbesar di Indonesia ini ternyata memiliki konsep sederhana dalam mengelola sumber daya manusianya. PT. Panairsan Pratama menggunakan sistem kekeluargaan yang diterapkan kepada karyawannya baik dari proses rekrutmen, pengelolaan SDM sehari hari sampai pada ketika karyawan perusahaan tersebut pensiun. Penilaian objektif maupun subjektif dari pemilik perusahaan akan menjadi dasar dalam berbagai hal terkait pengelolaan perusahaan yang berhubungan dengan karyawan seperti hal nya pemberian 
kompensasi, pengembangan karir dan lain sebagainya.

Perusahaan keluarga merupakan organisasi yang sangat unik. Isu yang melanda tidak hanya berasal dari kondisi eksternal bisnis semata. Perusahaan ini juga harus menghadapi masalah internal dari pemilik yang masih sedarah.

Budaya organisasi dalam PT. Panairsan tentunya memiliki warna yang berbeda dengan perusahaan terbuka biasa dimana faktor kepemimpinan menjadi hal yang paling utama dalam pembentukan budayanya. Keputusankeputusan diambil oleh para pihak keluarga dimana para professional yang bekerja didalam perusahaan ini hanya mengajukan sebuah usulan untuk membantu pengambilan keputusan. Like dan dislike pimpinan menjadi motivasi dan kepuasan kerja tersendiri bagi karyawan yang bekerja.

Toleransi terhadap kepentingan karyawan yang bekerja bisa di bilang cukup tinggi sehingga disiplin kerja bisa dapat dikatakan tidak terlalu ketat, namun para karyawan dituntut produktivitas tinggi karena perusahaan harus memenuhi kepuasan pelanggan dimana kita ketahui bersama bahwa pelanggan PT. Panairsan didominasi oleh instansi pemerintah.

Dengan kondisi pengelolaan SDM yang berasaskan kekeluargaan tersebut, maka akan sangat menarik untuk mengetahui bagaimana kepuasan dan produktivitas karyawan PT. Panairsan Pratama.

\section{KAJIAN PUSTAKA Budaya Organisasi}

Victor S.L. Tan dalam Wibowo (2016:15) mendefinisikan budaya korporasi sebagai cara orang melakukan sesuatu dalam organisasi. Budaya organisasi merupakan serangkaian norma terdiri dari keyakinan, sikap, nilai-nilai inti dan pola perilaku, dibagikan oleh orang dalam suatu organisasi. Kayakinan bersama, nilai-nilai inti dan pola perilaku mempengaruhi kinerja dalam organisasi.
Belief atau keyakinan adalah asumsi atau persepsi tentang sesuatu, orang dan organisasi secara keseluruhan, diterima sebagai sesuatu yang benar dan layak. Core values adalah nilai dominan atau inti, yang diterima di seluruh organisasi. Behavior pattern atau pola perilaku adalah cara orang bertindak satu sama lain.

\section{Kompensasi}

Kompensasi dalam Hamali (2016:78) dimaksudkan sebagai balas jasa (reward) perusahaan terhadap pengorbanan waktu, tenaga, dan pikiran yang telah diberikan karyawan kepada perusahaan. Selain itu menurut Edwin B. Filipo dalam Suwatno dan Priansa (2016:220) "compensation as the adequate and equitable remuneration of personal for their contribution to organization objektives". Kompensasi merupakan pemberian imbalan jasa yang layak dan adil kepada karyawan-karyawan karena mereka telah memberi sumbangan kepada pencapaian organisasi.

\section{Kepemimpinan}

Kepemimpinan atau leadership termasuk kelompok ilmu terapan atau applied science dari ilmu-ilmu sosial, sebab prinsip-prinsip dan rumusan- rumusannya bermanfaat dalam meningkatkan kesejahteraan manusia. Bone dan Kurtz dalam Suwatno dan Priansa (2016:140) mengemukakan bahwa kepemimpinan adalah tindakan memotivasi orang lain atau menyebabkan orang lain melakukan tugas tertentu dengan tujuan untuk mencapai tujuan spesifik.

\section{Disiplin Kerja}

Menurut Hamali (2016:214) disiplin adalah suatu kekuatan yang berkembang didalam tubuh karyawan dan menyebabkan karyawan dapat menyesuaikan dengan sukarela pada keputusan peraturan, dan nilainilai tinggi dari pekerjaan dan perilaku. Hamali (2016:215) juga menyebutkan disiplin 
karyawan adalah perilaku seorang yang sesuai dengan peraturan, prosedur kerja yang ada atau disiplin adalah sikap, tingkah laku, dan perbuatan yang sesuai dengan peraturan dari organisasi, baik tertulis maupun tidak tertulis.

\section{Motivasi}

Koldalkar dalam Hamali (2016:130) mendefinisikan motivasi sebagai hasrat dalam yang membakat yang disebabkan oleh kebutuhan, keinginan, dan kemauan yang mendorong seorang individu untuk menggunakan energi fisik dan mentalnya demi tercapainya tujuan-tujuan yang dinginkan.

\section{Kepuasan Kerja}

Robbins dalam Hamali (2016:200) mendefinisakan kepuasan kerja sebagai sikap umum terhadap pekerjaan seseorang, yang menunjukkan perbedaan antara jumlah penghargaan yang diterima pekerja dan jumlah yang diyakini oleh pekerja yang seharusnya diterima.

\section{Produktivitas Karyawan}

Ardana, Mujiati dan Utama (2012:270) menyatakan secara umum produktivitas dapat dikatakan sebagai perbandingan antara hasil yang dicapai dengan keseluruhan daya atau factor produksi yang dipergunakan. Sedangkan produktivitas kerja (tenaga kerja) adalah perbandingan antara hasil yang dicapai dengan peran serta tenaga kerja persatuan waktu. Atau sejumlah barang/jasa yang dapat dihasilkan oleh seseorang atau kelompok orang/karyawan dalam jangka waktu tertentu.

\section{Kerangka Pemikiran}

Berdasarkan rumusan masalah yang telah diuraikan mengenai Variabel Budaya Organisasi, Kompensasi, Kepemimpinan, Disiplin Kerja dan Motivasi yang berpengaruh terhadap Kepuasan Kerja berdampak pada Produktivitas Karyawan PT. Panairsan Pratama, maka paradigm penelitian dan kerangka pemikiran teoritis yang diajukan dalam penelitian ini digambarkan sebagai berikut :

\section{Gambar 1.}

Paradigma Peneliatian Path Analisis

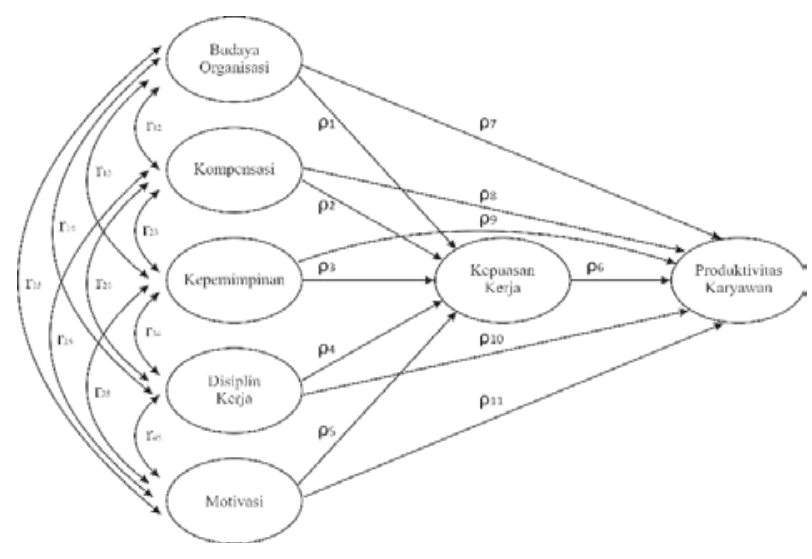

\section{Hipotesis}

Berdasarkan pada landasan teori dan kerangka pemikiran di atas, maka hipotesis dalam penelitian ini adalah sebagai berikut:

$\mathrm{H}_{1}$ : Budaya organisasi berpengaruh positif terhadap kepuasan kerja. Artinya semakin baik budaya organisasi perusahaan maka akan semakin tinggi tingkat kepuasan kerja karyawan PT. Panairsan Pratama

$\mathrm{H}_{2}$ : Kompensasi berpengaruh positif terhadap kepuasan kerja. Artinya semakin baik nilai kompensasi yang perusahaan berikan kepada karyawan maka akan semakin tinggi tingkat kepuasan kerja karyawan PT. Panarisan Pratama.

$\mathrm{H}_{3}$ : Kepemimpinan berpengaruh positif terhadap kepuasan kerja. Artinya semakin baik kepemimpinan dalam perusahaan maka akan semakin tinggi tingkat kepuasan kerja karyawan PT. Panairsan Pratama. 
$\mathrm{H}_{4}$ : Disiplin Kerja berpengaruh positif terhadap kepuasan kerja. Artinya semakin tinggi disiplin kerja karyawan akan semakin tinggi juga tingkat kepuasan kerja karyawan PT. Panairsan Pratama

$\mathrm{H}_{5}$ : Motivasi berpengaruh positif terhadap kepuasan kerja. Artinya semakin baik motivasi yang dimiliki oleh karyawan maka akan semakin tinggi pula tingkat kepuasan kerja karyawan PT. Panairsan Pratama

$\mathrm{H}_{6}$ : Budaya organisasi, kompensasi, kepemimpinan, disiplin kerja dan motivasi berpengaruh positif terhadap kepuasan kerja karyawan PT. Panairsan Pratama.

$\mathrm{H}_{7}$ : Kepemimpinan berpengaruh positif terhadap kepuasan kerja. Artinya semakin baik kepemimpinan dalam perusahaan maka akan semakin tinggi tingkat kepuasan kerja karyawan PT. Panairsan Pratama.

$\mathrm{H}_{3}$ : Budaya organisasi melalui kompensasi berpengaruh positif secara tidak langsung terhadap kepuasan kerja karyawan PT. Panairsan Pratama.

$\mathrm{H}_{8}$ : Budaya organisasi melalui kepemimpinan berpengaruh positif secara tidak langsung terhadap kepuasan kerja karyawan PT. Panairsan Pratama.

$\mathrm{H}_{9}$ : Budaya organisasi melalui disiplin kerja berpengaruh positif secara tidak langsung terhadap kepuasan kerja karyawan PT. Panairsan Pratama.

$\mathrm{H}_{10}$ : Budaya organisasi melalui motivasi berpengaruh positif secara tidak langsung terhadap kepuasan kerja karyawan PT. Panairsan Pratama.

$\mathrm{H}_{11}$ : Kompensasi melalui kepemimpinan berpengaruh positif secara tidak langsung terhadap kepuasan kerja karyawan PT. Panairsan Pratama.

$\mathrm{H}_{12}$ : Kompensasi melalui disiplin kerja berpengaruh positif secara tidak langsung terhadap kepuasan kerja karyawan PT. Panairsan Pratama.

$\mathrm{H}_{13}$ : Kompensasi melalui motivasi berpengaruh positif secara tidak langsung terhadap kepuasan kerja karyawan PT. Panairsan Pratama.

$\mathrm{H}_{14}$ : Kepemimpinan melalui disiplin kerja berpengaruh positif secara tidak langsung terhadap kepuasan kerja karyawan PT. Panairsan Pratama.

$\mathrm{H}_{15}$ : Kepemimpinan melalui motivasi berpengaruh positif secara tidak langsung terhadap kepuasan kerja karyawan PT. Panairsan Pratama.

$\mathrm{H}_{16}$ : Disiplin Kerja melalui motivasi berpengaruh positif secara tidak langsung terhadap kepuasan kerja karyawan PT. Panairsan Pratama.

$\mathrm{H}_{17}$ : Kepuasan kerja berpengaruh positif terhadap produktivitas Karyawan. Artinya bila kepuasan kerja karyawan meningkat maka produktivitas karyawan PT. Panairsan Pratama juga akan meningkat.

$\mathrm{H}_{18}$ : Budaya Organisasi berpengaruh positif terhadap produktivitas Karyawan. Artinya bila kepuasan kerja karyawan meningkat maka produktivitas karyawan PT. Panairsan Pratama juga akan meningkat.

$\mathrm{H}_{19}$ : Kompensasi berpengaruh positif terhadap produktivitas. Artinya semakin baik nilai kompensasi yang perusahaan berikan kepada karyawan maka akan semakin tinggi tingkat produktivitas karyawan PT. Panarisan Pratama.

$\mathrm{H}_{20}$ : Kepemimpinan berpengaruh positif terhadap produktivitas. Artinya semakin baik kepemimpinan dalam perusahaan maka akan semakin tinggi tingkat produktivitas karyawan PT. Panairsan Pratama.

$\mathrm{H}_{21}$ : Disiplin Kerja berpengaruh positif terhadap produktivitas. Artinya semakin tinggi disiplin kerja karyawan 
akan semakin tinggi juga tingkat produktivitas karyawan PT. Panairsan Pratama.

$\mathrm{H}_{22}$ : Motivasi berpengaruh positif terhadap produktivitas. Artinya semakin baik motivasi yang dimiliki oleh karyawan maka akan semakin tinggi pula tingkat produktivitas karyawan PT. Panairsan Pratama.

$\mathrm{H}_{23}$ : Budaya organisasi, kompensasi, kepemimpinan, disiplin kerja dan motivasi melalui kepuasan kerja berpengaruh positif terhadap produktivitas karyawan PT. Panairsan Pratama.

$\mathrm{H}_{24}$ : Budaya organisasi melalui kompensasi berpengaruh positif secara tidak langsung terhadap produktivitas karyawan PT. Panairsan Pratama.

$\mathrm{H}_{25}$ : Budaya organisasi melalui kepemimpinan berpengaruh positif secara tidak langsung terhadap produktivitas karyawan PT. Panairsan Pratama.

$\mathrm{H}_{26}$ : Budaya organisasi melalui disiplin kerja berpengaruh positif secara tidak langsung terhadap produktivitas karyawan PT. Panairsan Pratama.

$\mathrm{H}_{27}$ : Budaya organisasi melalui motivasi berpengaruh positif secara tidak langsung terhadap produktivitas karyawan PT. Panairsan Pratama.

$\mathrm{H}_{28}$ : Kompensasi melalui kepemimpinan berpengaruh positif secara tidak langsung terhadap produktivitas karyawan PT. Panairsan Pratama.

$\mathrm{H}_{29}$ : Kompensasi melalui disiplin kerja berpengaruh positif secara tidak langsung terhadap produktivitas karyawan PT. Panairsan Pratama.
$\mathrm{H}_{30}$ : Kompensasi melalui motivasi berpengaruh positif secara tidak langsung terhadap produktivitas karyawan PT. Panairsan Pratama.

$\mathrm{H}_{31}$ : Kepemimpinan melalui disiplin kerja berpengaruh positif secara tidak langsung terhadap produktivitas karyawan PT. Panairsan Pratama.

$\mathrm{H}_{32}$ : Kepemimpinan melalui motivasi berpengaruh positif secara tidak langsung terhadap produktivitas karyawan PT. Panairsan Pratama.

$\mathrm{H}_{33}$ : Disiplin Kerja melalui motivasi berpengaruh positif secara tidak langsung terhadap produktivitas karyawan PT. Panairsan Pratama.

\section{METODE PENELITIAN \\ Waktu dan Tempat Penelitian}

Penelitian ini dilakukan di PT. Panairsan Pratama yang beralamat di Kedoya Elok Plaza Blok DB No.23 Jl. Panjang Kebon Jeruk Jakarta Barat dan Pabrik PT. Panairsan Pratama yang terletak di Cimahi. Penelitian ini dilaksanakan \pm 6 bulan, pada bulan Januari 2018 sampai dengan Juni 2018.

\section{Populasi dan Sampel}

Populasi dalam penelitian ini adalahkaryawan PT. Panairsan Pratama yang terletak di kantorpusat yang terletak di Jakarta danpabrik yang terletak di Cimahi.

Sampel penelitian ini tidak menggunakan rumus Slovin dikarenakan jumlah karyawan PT. Panairsan Pratama hanya 60 orang karyawan karena jumlah karyawan yang masih sedikit.

Teknik pengambilan sampel yang digunakan dalam penelitian ini adalah proportional stratified random sampling yang merupakan bagian dari teknik pengambilan sampling probability sampling dimana penulis mengambil $70 \%$ sample dari tiap tahapan jabatan karyawan dan diperoleh sejumlah 42 karyawan. 


\section{Variabel Operasional Budaya Organisasi $\left(\mathrm{X}_{1}\right)$}

Stephen P. Robbins dalam Wibowo (2016:15) budaya organisasi adalah sebuah persepsi umum yang dipegang oleh anggota organisasi, suatu sistem tentang keberartian bersama. Budaya organisasi berkepentingan dengan bagaimana pekerja merasakan karakteristik suatu budaya organisasi, tidak dengan apakah seperti mereka atau tidak. Sub variabel yang digunakan meliputi:
1. Innovation
2. Stability
3. Orientitation
4. Result Orientation
5. Easygoing
6. Attention to detail
7. Collaboration orientation
8. Identitas Organisasi
9. Komitmen Kolektif
10. Membentuk Prilaku

\section{Kompensasi $\left(\mathrm{X}_{2}\right)$}

Edwin B. Filipo dalam Suwatno dan Priansa (2016:220) "compensation as the adequate and equitable remuneration of personal for their contribution to organization objektives”. Kompensasi merupakan pemberian imbalan jasa yang layak dan adil kepada karyawan-karyawan karena mereka telah memberi sumbangan kepada pencapaian organisasi. Sub variabel yang digunakan meliputi:

1. Asas Keadilan

2. Asas Kelayakan dan Kewajaran

3. Ikatan Kerjasama

4. Kepuasan Kerja

5. Pengadaan Efektif

6. Motivasi

7. Menjamin Keadilan

8. Disiplin

9. Pengaruh Serikat Pekerja

10. Pengaruh Pemerintah

\section{Kepemimpinan $\left(\mathrm{X}_{3}\right)$}

Bone dan Kurtz dalam Suwatno dan Priansa (2016:140) mengemukakan bahwa kepemimpinan adalah tindakan memotivasi orang lain atau menyebabkan orang lain melakukan tugas tertentu dengan tujuan untuk mencapai tujuan spesifik. Sub variabel yang digunakan meliputi:

1. Asas Keadilan

2. Asas Kelayakan dan Kewajaran

\section{Disiplin Kerja $\left(\mathrm{X}_{4}\right)$}

Hamali (2016:215) juga menyebutkan disiplin karyawan adalah perilaku seorang yang sesuai dengan peraturan, prosedur kerja yang ada atau disiplin adalah sikap, tingkah laku, dan perbuatan yang sesuai dengan peraturan dari organisasi, baik tertulis maupun tidak tertulis. Dimensi dalam variable ini meliputi :

1. Cerminan suasana dari disiplin yang baik.

2. Faktor-faktor yang mempengaruhi disiplin karyawan

\section{Motivasi $\left(\mathrm{X}_{5}\right)$}

Koldalkar dalam Hamali (2016:130) mendefinisikan motivasi sebagai hasrat dalam yang membakat yang disebabkan oleh kebutuhan, keinginan, dan kemauan yang mendorong seorang individu untuk menggunakan energi fisik dan mentalnya demi tercapainya tujuan-tujuan yang dinginkan citra perusahaan. Dimensi yang meliputi variabel ini adalah :

1. Motivasi interinsik

2. Motivasi ekstrinsik

3. Lima tingkatan atau hierarki kebutuhan

\section{Kepuasan Kerja (Y)}

Robbins dalam Hamali (2016:200) mendefinisakan kepuasan kerja sebagai sikap umum terhadap pekerjaan seseorang, yang menunjukkan perbedaan antara jumlah penghargaan yang diterima pekerja dan jumlah yang diyakini oleh pekerja yang 
seharusnya diterima. Dimensi variabel yang digunakan terdiri dari :

1. Discrepancy Theory,

2. Equity Theory

3. Variabel Kepuasasn Kerja.

4. Aspek-aspek Kepuasan Kerja

\section{Produktivitas (Z)}

Ardana, Mujiati dan Utama (2012:270) mengartikan produktivitas kerja (tenaga kerja) adalah perbandingan antara hasil yang dicapai dengan peran serta tenaga kerja persatuan waktu. Atau sejumlah barang/jasa yang dapat dihasilkan oleh seseorang atau kelompok orang/karyawan dalam jangka waktu tertentu. Dimensi yang meliputi varibel ini diantaranya:

1. Job Satisfaction

2. Waste \& Scrapt

3. Quality Record

4. Absenteeism \& Tardness

5. Report From Counselor

6. Grievances

7. Accident Report

8. Medical Report

9. Suggestion

\section{Metode Analisis}

Kuesioner dibagikan kepada 42 karyawan kemudian data diolah, diuji terlebih dahulu reabilitas dan validitasnya. Kemudian teknik analisis data yang digunakan adalah uji asumsi klasik dan path analisis.

\section{HASIL PENELITIAN DAN PEMBAHASAN \\ Karakteristik Responden}

Mayoritas jenis kelamin responden adalah laki-laki yaitu sebesar 88,09\% dan $11,91 \%$ perempuan. Usia responden 21$<30$ th sebesar $23,80 \%$, usia $30-<40$ th $38,10 \%$ dan sisanya yaitu $\geq 40$ sebesar $38,10 \%$.

Jabatan pekerjaan respoden sebagai Staff sebesar 80,95\%, Supervisor 9,525\% dan
Manager sebesar 9,525\%. Pendidikan terakhir responden SD sebesar 4,76\%, SMP sebesar 14,29\%, SMA sebesar 52,38\% diikuti dengan S1 sebesar 26,19\% dan sisanya S2 sebesar $2,38 \%$.

\section{Analisis Data}

\section{Uji Validitas dan Uji Reabilitas}

Pengujian ini menggunakan SPSS versi 22, jika variabel $X_{1}, X_{2}, X_{3}, X_{4}, X_{5}, Y$ dan $Z$ nilai $r$ hitung $>r$ kritis yaitu 0,30 dan signifikansi di bawah 0,05 maka variabel tersebut valid. Dari hasil uji validitas bahwa semua variabel $\mathrm{X}_{1}, \mathrm{X}_{2}, \mathrm{X}_{3}, \mathrm{X}_{4}, \mathrm{X}_{5}, \mathrm{Y}$ dan $\mathrm{Z}$ adalah valid.

Kemudian uji reabilitas digunakan perolehan Cronbach's Alpha dimana kuesioner dikatakan reliabel jika nilai Cronbach's Alpha lebih besar 0,7. Adapun nilai dari keseluruhan variabel yang digunakan dalam penelitian ini yaitu $\mathrm{X}_{1}, \mathrm{X}_{2}, \mathrm{X}_{3}, \mathrm{X}_{4}, \mathrm{X}_{5}$, $\mathrm{Y}$ dan $\mathrm{Z}$ lebih besar dari 0,7 sehingga seluruh pernyataan dalam setiap variabel dapat dikatakan reliabel.

\section{Uji Asumsi Klasik}

\section{Uji Normalitas}

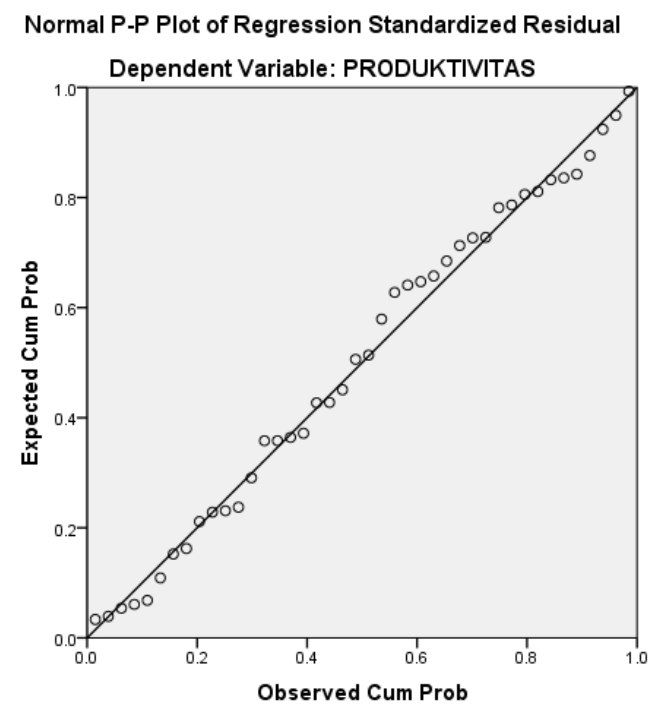

Gambar 2. P-P Plot Residual 1 


\section{Gambar 3. P-P Plot Residual II}

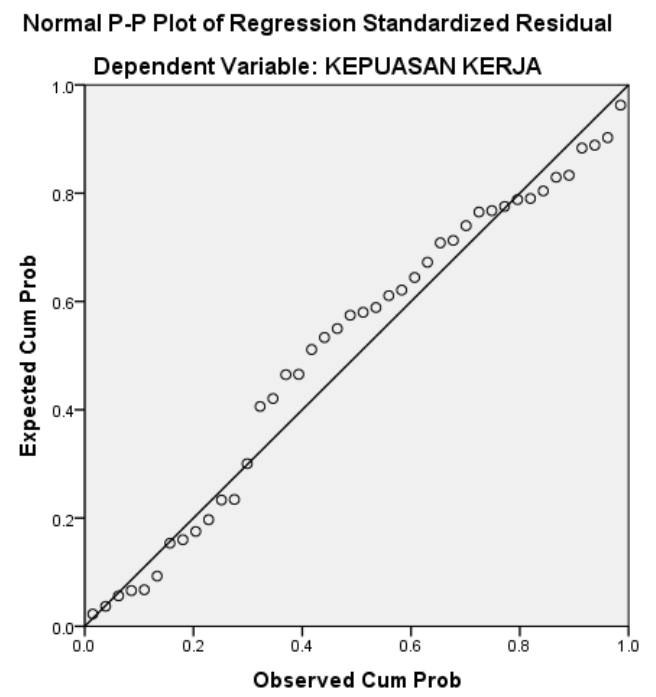

Tampilan grafik pada dua gambar di atas terlihat jelas bahwa grafik histogram variabel kepuasan kerja dan variable produktivitas mengikuti bentuk garis, maka dapat disimpulkan bahwa grafik PP Plot memberikan pola distribusi yang normal.

\section{Uji Heteroskedastisitas}

Gambar 4.

\section{Diagram Heteroskedastisitas Residual 1}

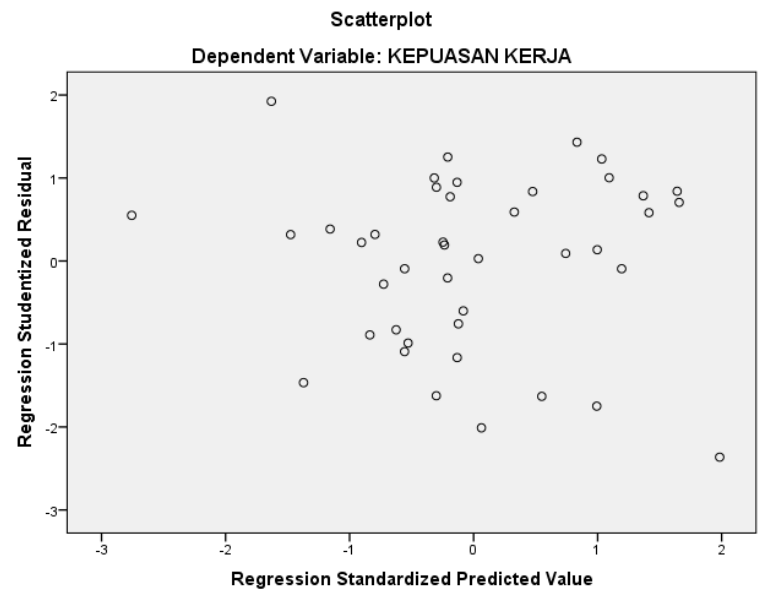

Diagram Heteroskedastisitas Residual 2

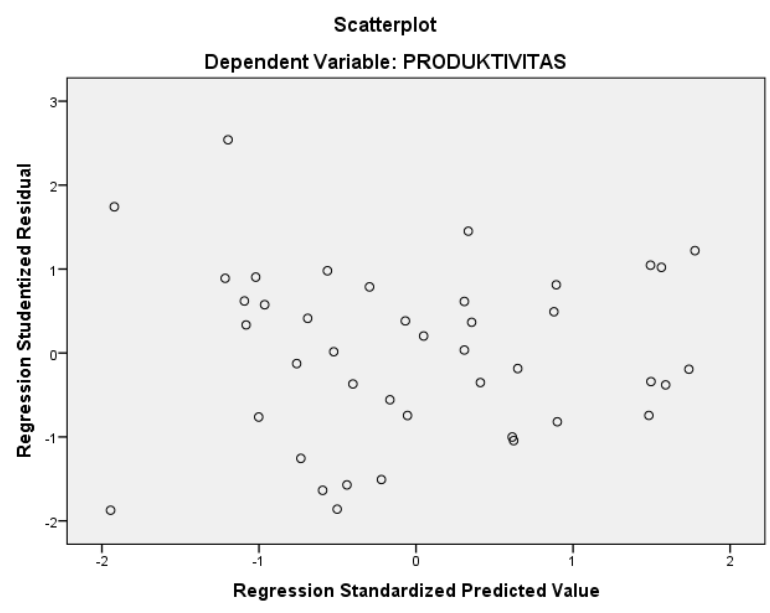

Berdasarkan dua gambar di atas maka residual pertama yang terdiri atas 5 variabel bebas $\left(\mathrm{X}_{1} \mathrm{X}_{2} \mathrm{X}_{3} \mathrm{X}_{4} \mathrm{X}_{5}\right)$ dan 1 variabel terikat (Y) ini adalah normal (terdistribusi secara merata). Sedangkan dari hasil berikutnya diperoleh, maka residual kedua yang terdiri atas 1 variabel bebas (Y) dan 1 variabel terikat (Z) ini adalah normal (terdistribusi secara merata). 


\section{Analisis Verifikatif Koefisien Korelasi}

\section{Tabel 1. Hasil Uji Korelasi Instrumen Variabel Independen $\left(X_{1}\right),\left(X_{2}\right),\left(X_{3}\right),\left(X_{4}\right)$, dan $\left(X_{5}\right)$}

\begin{tabular}{|c|c|c|c|c|c|c|}
\hline \multicolumn{7}{|c|}{ Correlations } \\
\hline & & $\begin{array}{c}\text { BUD } \\
\text { AYA } \\
\text { ORG } \\
\text { ANIS } \\
\text { ASI }\end{array}$ & $\begin{array}{c}\text { KOM } \\
\text { PENS } \\
\text { ASI }\end{array}$ & $\begin{array}{c}\text { KEPE } \\
\text { MIM } \\
\text { PINA } \\
\mathrm{N}\end{array}$ & $\begin{array}{c}\text { DISIP } \\
\text { LIN } \\
\text { KERJ } \\
\text { A }\end{array}$ & $\begin{array}{c}\text { MOT } \\
\text { IVAS } \\
\text { I }\end{array}$ \\
\hline $\begin{array}{l}\text { BUDAYA } \\
\text { ORGANI } \\
\text { SASI }\end{array}$ & $\begin{array}{l}\text { Pearson } \\
\text { Correlati } \\
\text { on } \\
\text { Sig. (2- } \\
\text { tailed) } \\
\mathrm{N}\end{array}$ & 42 & $\begin{array}{r}.695^{* * *} \\
.000 \\
42\end{array}$ & $\begin{array}{r}.692^{* *} \\
.000 \\
42\end{array}$ & $\begin{array}{r}.734^{* *} \\
.000 \\
42\end{array}$ & $\begin{array}{r}.698^{*} \\
.000 \\
42\end{array}$ \\
\hline $\begin{array}{l}\text { KOMPEN } \\
\text { SASI }\end{array}$ & $\begin{array}{l}\text { Pearson } \\
\text { Correlati } \\
\text { on } \\
\text { Sig. (2- } \\
\text { tailed) } \\
\mathrm{N}\end{array}$ & $\begin{array}{r}.695^{* *} \\
.000 \\
42\end{array}$ & 42 & $\begin{array}{r}.669^{* *} \\
.000 \\
42\end{array}$ & $\begin{array}{r}.732^{* *} \\
.000 \\
42\end{array}$ & $\begin{array}{r}.000 \\
42\end{array}$ \\
\hline $\begin{array}{l}\text { KEPEMI } \\
\text { MPINAN }\end{array}$ & $\begin{array}{l}\text { Pearson } \\
\text { Correlati } \\
\text { on }\end{array}$ & $.692^{* *}$ & $.669^{* *}$ & 1 & $.777^{* *}$ & $.725^{*}$ \\
\hline & $\begin{array}{l}\text { Sig. (2- } \\
\text { tailed) } \\
\mathrm{N}\end{array}$ & $\begin{array}{r}.000 \\
42\end{array}$ & .000 & 42 & .000 & $\begin{array}{r}.000 \\
42 \\
\end{array}$ \\
\hline $\begin{array}{l}\text { DISIPLIN } \\
\text { KERJA }\end{array}$ & $\begin{array}{l}\text { Pearson } \\
\text { Correlati } \\
\text { on } \\
\text { Sig. (2- } \\
\text { tailed) } \\
\mathrm{N}\end{array}$ & $\begin{array}{r}.734^{* * *} \\
.000 \\
42\end{array}$ & $\begin{array}{r}.732^{* *} \\
.000 \\
42\end{array}$ & $\begin{array}{r}.777^{* *} \\
.000 \\
42\end{array}$ & 42 & $\begin{array}{r}.737^{*} \\
\\
.000 \\
42\end{array}$ \\
\hline $\begin{array}{l}\text { MOTIVA } \\
\text { SI }\end{array}$ & $\begin{array}{l}\text { Pearson } \\
\text { Correlati } \\
\text { on } \\
\text { Sig. (2- } \\
\text { tailed) } \\
\mathrm{N}\end{array}$ & $\begin{array}{r}.000 \\
42\end{array}$ & $.802^{* *}$ & $\begin{array}{r}.725^{* *} \\
.000 \\
42\end{array}$ & $\begin{array}{r}.000 \\
42\end{array}$ & 42 \\
\hline
\end{tabular}

Pada model path analisis ini, langkah pertama untuk melakukan analisis verifikatif adalah mencari koefisien korelasi antar variabel bebas (independent). Berikut ini adalah tabel yang berisi uji korelasi variabel bebas budaya organisasi $\left(\mathrm{X}_{1}\right)$, kompensasi $\left(\mathrm{X}_{2}\right)$, kepemimpinan $\left(\mathrm{X}_{3}\right)$, disiplin kerja $\left(\mathrm{X}_{4}\right)$, dan motivasi $\left(\mathrm{X}_{5}\right)$. Dari tabel di atas dapat kita peroleh koefisien korelasi antara budaya organisasi $\left(\mathrm{X}_{1}\right)$ dengan kompensasi $\left(\mathrm{X}_{2}\right)$ sebesar 0,695 artinya terdapat hubungan atau korelasi antara variabel budaya organisasi $\left(\mathrm{X}_{1}\right)$ dengan kompensasi $\left(\mathrm{X}_{2}\right)$ yang termasuk dalam kategori kuat.

Koefisien korelasi antara budaya organisasi $\left(\mathrm{X}_{1}\right)$ dengan kepemimpinan $\left(\mathrm{X}_{3}\right)$ sebesar 0,692 artinya terdapat hubungan atau korelasi antara variabel budaya organisasi $\left(\mathrm{X}_{1}\right)$ dengan kepemimpinan $\left(\mathrm{X}_{3}\right)$ yang termasuk dalam kategori kuat.

Koefisien korelasi antara budaya organisasi $\left(\mathrm{X}_{1}\right)$ dengan disiplin kerja $\left(\mathrm{X}_{4}\right)$ sebesar 0,734 artinya terdapat hubungan atau korelasi antara variabel budaya organisasi $\left(\mathrm{X}_{1}\right)$ dengan disiplin kerja $\left(\mathrm{X}_{4}\right)$ yang termasuk dalam kategori kuat.

Koefisien korelasi antara budaya organisasi $\left(\mathrm{X}_{1}\right)$ dengan motivasi $\left(\mathrm{X}_{5}\right)$ sebesar 0,698 artinya terdapat hubungan atau korelasi antara variabel budaya organisasi $\left(\mathrm{X}_{1}\right)$ dengan motivasi $\left(\mathrm{X}_{5}\right)$ yang termasuk dalam kategori kuat.

Koefisien korelasi antara kompensasi $\left(\mathrm{X}_{2}\right)$ dengan kepemimpinan $\left(\mathrm{X}_{3}\right)$ sebesar 0,669 artinya terdapat hubungan atau korelasi antara variabel kompensasi $\left(\mathrm{X}_{2}\right)$ dengan kepemimpinan $\left(\mathrm{X}_{3}\right)$ yang termasuk dalam kategori kuat.

Koefisien korelasi antara kompensasi $\left(\mathrm{X}_{2}\right)$ dengan disiplin kerja $\left(\mathrm{X}_{4}\right)$ sebesar 0,732 artinya terdapat hubungan atau korelasi antara variabel kompensasi $\left(\mathrm{X}_{2}\right)$ dengan disiplin kerja $\left(\mathrm{X}_{4}\right)$ yang termasuk dalam kategori kuat.

Koefisien korelasi antara kompensasi $\left(\mathrm{X}_{2}\right)$ dengan motivasi $\left(\mathrm{X}_{5}\right)$ sebesar 0,802 artinya terdapat hubungan atau korelasi antara variabel kompensasi $\left(\mathrm{X}_{2}\right)$ dengan motivasi $\left(\mathrm{X}_{5}\right)$ yang termasuk dalam kategori sangat kuat.

Koefisien korelasi antara kepemimpinan $\left(\mathrm{X}_{3}\right)$ dengan disiplin kerja $\left(\mathrm{X}_{4}\right)$ sebesar 0,777 artinya terdapat hubungan atau korelasi antara 
variabel kepemimpinan $\left(\mathrm{X}_{3}\right)$ dengan disiplin kerja $\left(\mathrm{X}_{4}\right)$ yang termasuk dalam kategori kuat.

Koefisien korelasi antara kepemimpinan $\left(\mathrm{X}_{3}\right)$ dengan motivasi $\left(\mathrm{X}_{5}\right)$ sebesar 0,725 artinya terdapat hubungan atau korelasi antara variabel kepemimpinan $\left(\mathrm{X}_{3}\right)$ dengan motivasi $\left(\mathrm{X}_{5}\right)$ yang termasuk dalam kategori kuat.

Koefisien korelasi antara disiplin kerja $\left(\mathrm{X}_{4}\right)$ dengan motivasi $\left(\mathrm{X}_{5}\right)$ sebesar 0,737 artinya terdapat hubungan atau korelasi antara variabel disiplin kerja $\left(\mathrm{X}_{4}\right)$ dengan motivasi $\left(\mathrm{X}_{5}\right)$ yang termasuk dalam kategori kuat.

\begin{tabular}{|l|c|r|r|r|}
\multicolumn{5}{|c|}{ Model Summary } \\
\hline Model & R & R Square & $\begin{array}{c}\text { Adjusted R } \\
\text { Square }\end{array}$ & $\begin{array}{r}\text { Std. Error of } \\
\text { the Estimate }\end{array}$ \\
\hline 1 & $.813^{\mathrm{a}}$ & .661 & .614 & 2.99588 \\
\hline
\end{tabular}

a. Predictors: (Constant), Motivasi, Budaya Organisasi, Kepemimpinan, Kompensasi, Disiplin Kerja

\section{Koefisien Regresi}

Tabel 2. Hasil Regresi Instrumen Variabel Independen $\left(X_{1}\right),\left(X_{2}\right),\left(X_{3}\right),\left(X_{4}\right)$, dan $\left(X_{5}\right)$ terhadap $(Y)$

ANOVA $^{\mathrm{a}}$

\begin{tabular}{|r|r|r|r|r|r|}
\hline \multicolumn{1}{|c|}{ Model } & $\begin{array}{r}\text { Sum of } \\
\text { Squares }\end{array}$ & Df & $\begin{array}{r}\text { Mean } \\
\text { Square }\end{array}$ & F & Sig. \\
\hline $1 \quad \begin{array}{l}\text { Regressi } \\
\text { on }\end{array}$ & 630.472 & 5 & 126.094 & $\begin{array}{r}14.04 \\
9\end{array}$ & $.000^{\mathrm{b}}$ \\
& & & & \\
Residual & 323.110 & 36 & 8.975 & & \\
Total & 953.582 & 41 & & & \\
\hline
\end{tabular}

a. Dependent Variable: Kepuasan Kerja

b. Predictors: (Constant), Motivasi, Budaya Organisasi, Kepemimpinan, Kompensasi, Disiplin Kerja

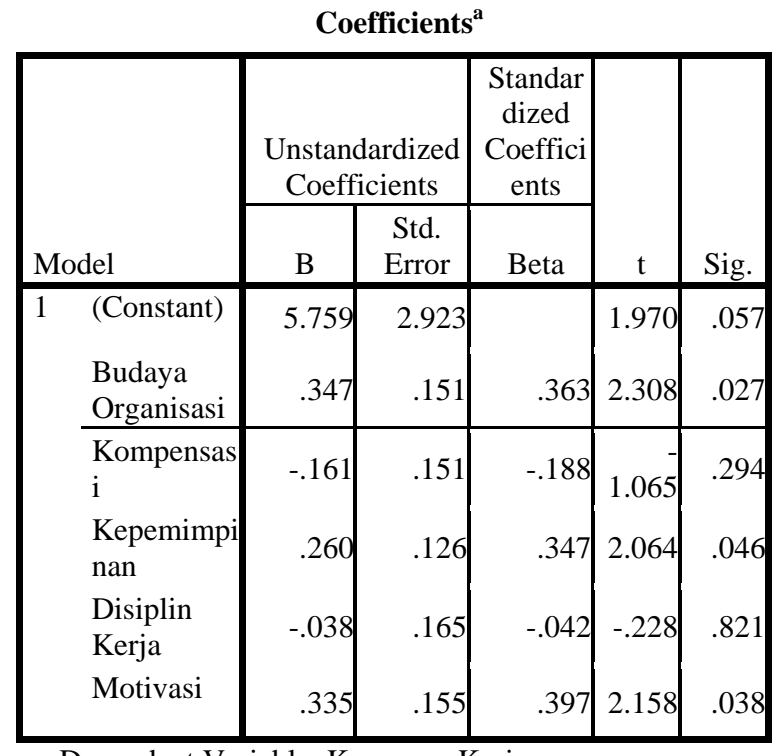

a. Dependent Variable: Kepuasan Kerja

Dari tabel 2. dapat diperoleh :

a. Nilai koefisien regresi $\mathrm{X} 1$ ke $\mathrm{Y}$ adalah 0,363

b. Nilai koefisien regresi X2 ke $\mathrm{Y}$ adalah 0,188

c. Nilai koefisien regresi $\mathrm{X} 3$ ke $\mathrm{Y}$ adalah 0,347

d. Nilai koefisien regresi X4 ke $\mathrm{Y}$ adalah 0,042

e. Nilai koefisien regresi X5 ke $\mathrm{Y}$ adalah 0,397

Tabel 3. Hasil Regresi Instrumen Variabel Independen (Y) terhadap (Z)

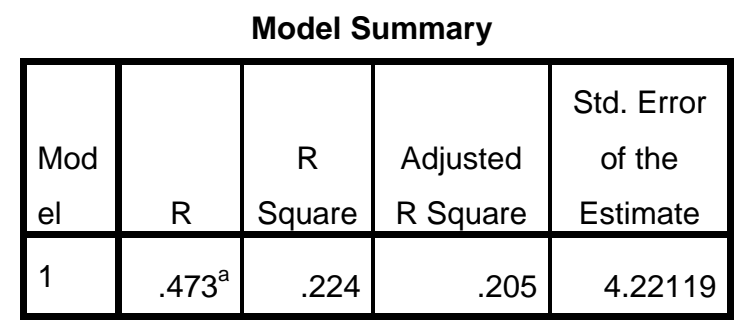

a. Predictors: (Constant), Kepuasan Kerja 


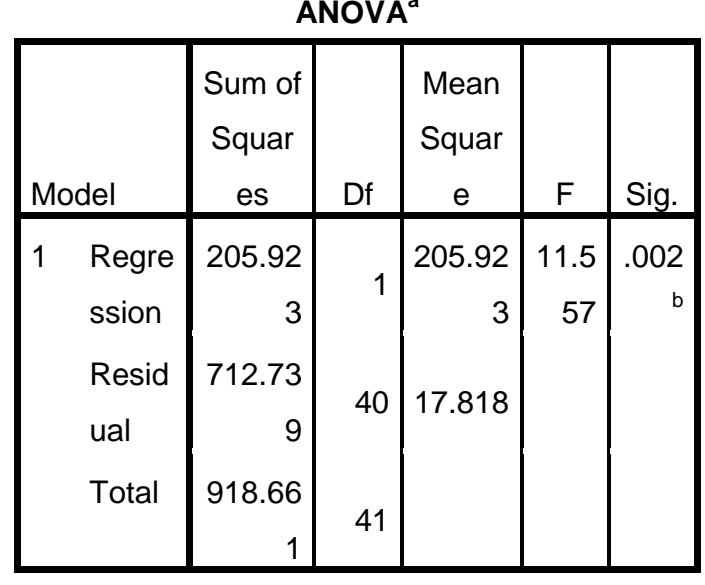

a. Dependent Variable: Produktivitas

b. Predictors: (Constant), Kepuasan Kerja

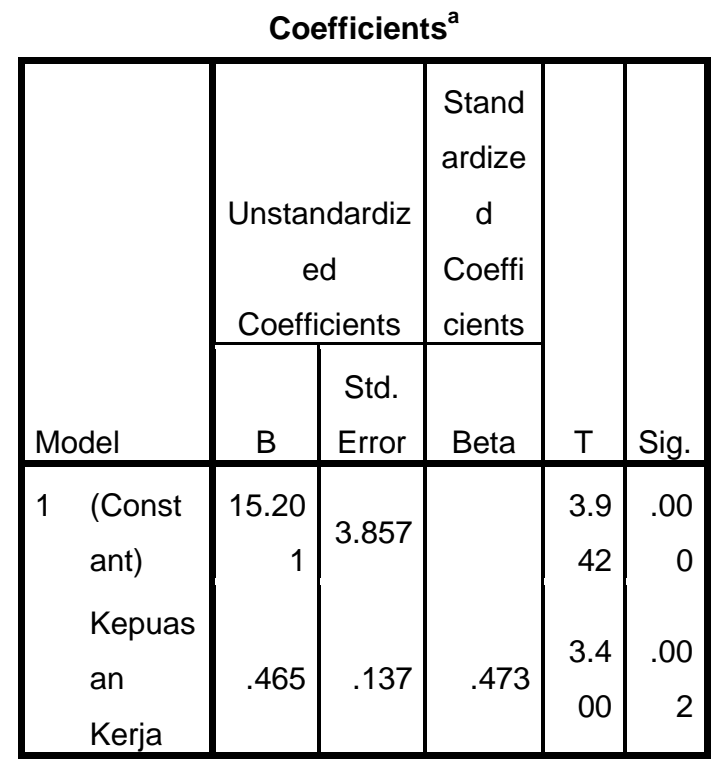

a. Dependent Variable: Produktivitas

Dari tabel 3. diperoleh koefisien regresi variabel Kepuasan Kerja (Y) ke variabel Produktivitas (Z) sebesar 0,473. Sehingga secara keseluruhan diperoleh : a. Nilai koefisien regresi $\mathrm{X} 1$ ke $\mathrm{Y}$ adalah 0,363

b. Nilai koefisien regresi $\mathrm{X} 2$ ke $\mathrm{Y}$ adalah 0,188

\begin{tabular}{|c|c|c|c|c|}
\hline \multicolumn{5}{|c|}{ Model Summary } \\
\hline $\begin{array}{l}\text { Mod } \\
\text { el }\end{array}$ & $\mathrm{R}$ & $\begin{array}{c}\mathrm{R} \\
\text { Square }\end{array}$ & $\begin{array}{l}\text { Adjusted } \\
\text { R Square }\end{array}$ & $\begin{array}{l}\text { Std. Error } \\
\text { of the } \\
\text { Estimate }\end{array}$ \\
\hline 1 & $.628^{a}$ & .394 & .290 & 3.98815 \\
\hline
\end{tabular}

a. Predictors: (Constant), Kepuasan Kerja, Kompensasi, Disiplin Kerja, Budaya Organisasi, Kepemimpinan, Motivasi

c. Nilai koefisien regresi $\mathrm{X} 3$ ke $\mathrm{Y}$ adalah 0,347

d. Nilai koefisien regresi $\mathrm{X} 4$ ke $\mathrm{Y}$ adalah 0,042

e. Nilai koefisien regresi X5 ke $\mathrm{Y}$ adalah 0,397

f. Nilai koefisien regresi Y ke Z adalah 0,473

Tabel 4. Hasil Regresi Instrumen Variabel Independen $\left(X_{1}\right),\left(X_{2}\right),\left(X_{3}\right),\left(X_{4}\right)$, dan $\left(X_{5}\right)$ terhadap $(Z)$ 


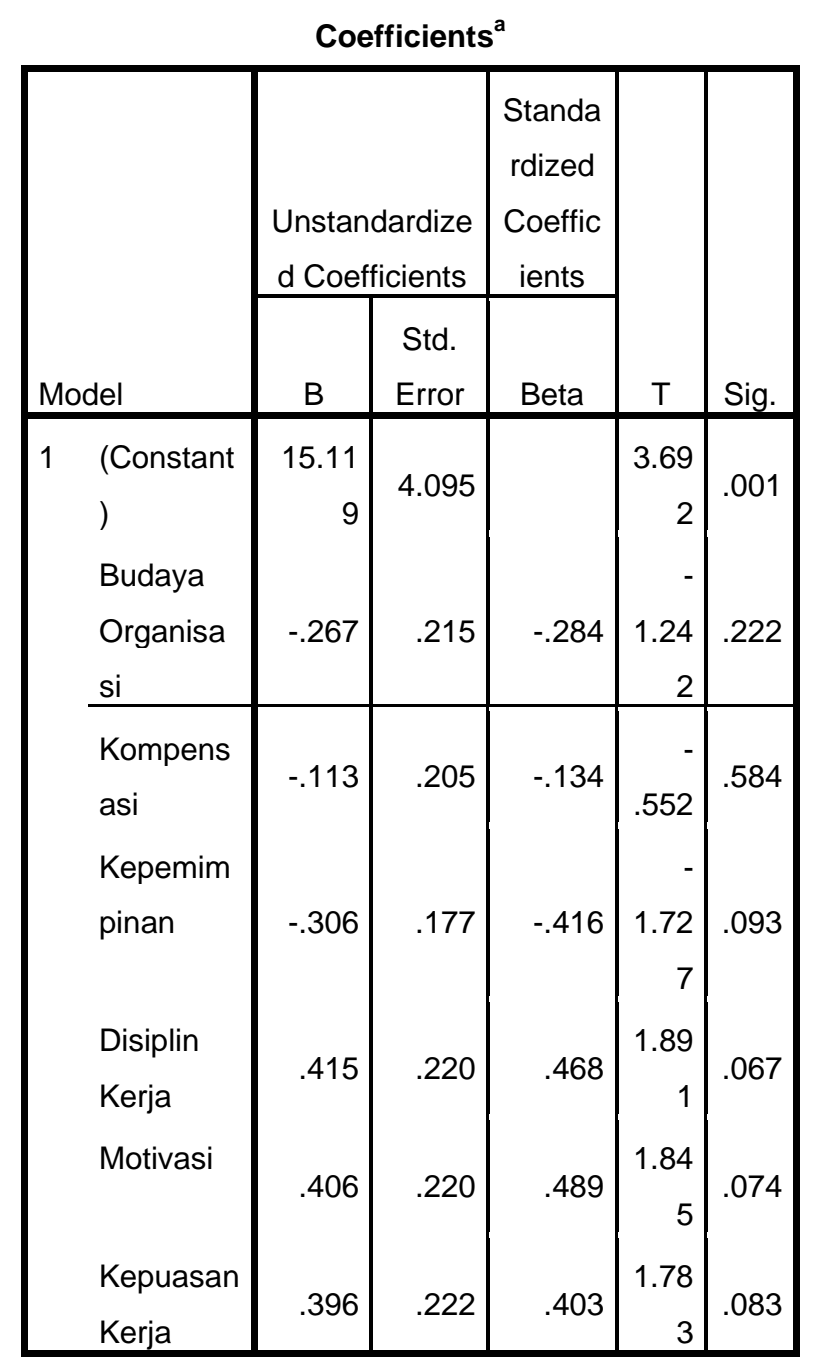

a. Dependent Variable: Produktivitas

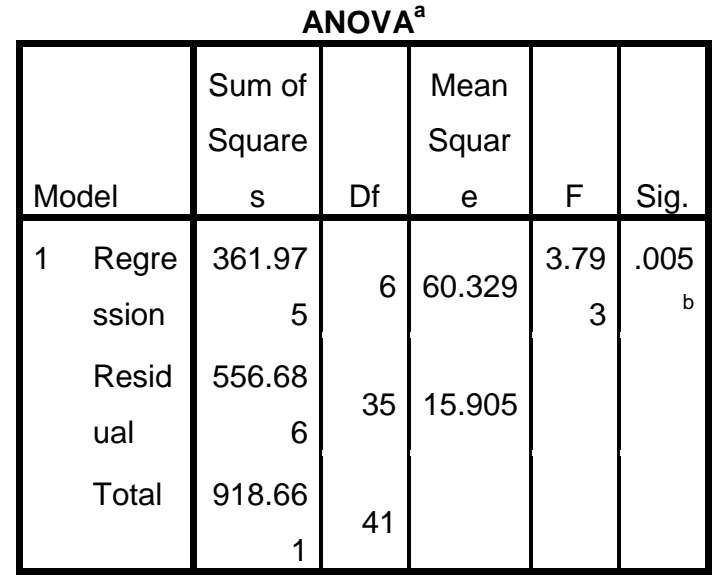

a. Dependent Variable: Produktivitas

b. Predictors: (Constant), Kepuasan Kerja, Kompensasi, Disiplin Kerja, Budaya Organisasi, Kepemimpinan, Motivasi

Dari tabel 4 diperoleh koefisien regresi variabel Kepuasan Kerja (Y) ke variabel Produktivitas (Z) sebesar 0,628. Sehingga secara keseluruhan diperoleh :

a. Nilai koefisien regresi X1 ke Z adalah 0,284

b. Nilai koefisien regresi X2 ke Z adalah 0,134

c. Nilai koefisien regresi X3 ke Z adalah 0,416

d. Nilai koefisien regresi X4 ke Z adalah 0,468

e. Nilai koefisien regresi X5 ke Z adalah 0,489

f. Nilai koefisien regresi $\mathrm{Y}$ ke $\mathrm{Z}$ adalah 0,403 


\section{Analisis Verifikatif Path Analisis}

\section{Gambar 6. Path Analisis}

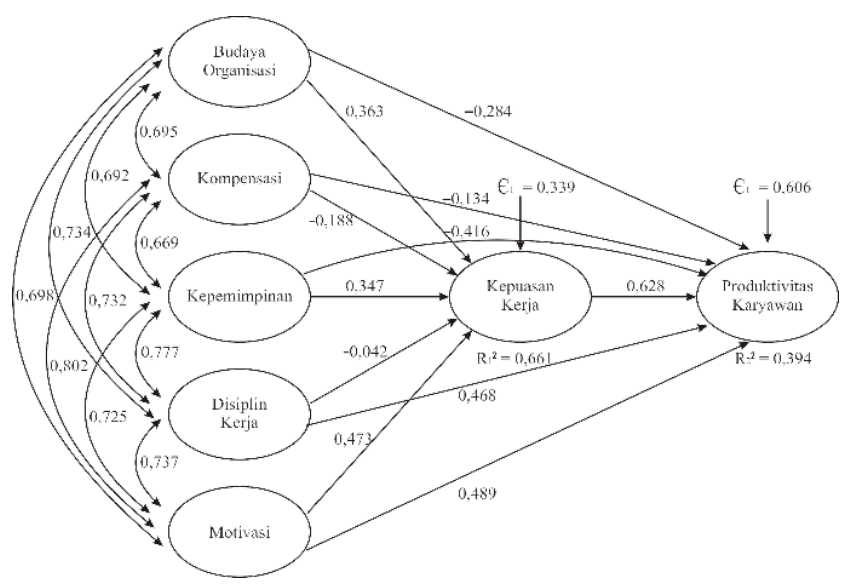

Dari gambar 6. analisis jalur di atas dapat dikatakan bahwa :

a. Variabel Budaya Organisasi (X1) dan Kompensasi (X2) berhubungan atau berkorelasi dengan nilai koefisien korelasi sebesar 0,695. Ini menunjukkan bahwa ada korelasi atau hubungan yang kuat antara variabel Budaya Organisasi (X1) dan Kompensasi (X2).

b. Variabel Budaya Organisasi (X1) dan Kepemimpinan (X3) berhubungan atau berkorelasi dengan nilai koefisien korelasi sebesar 0,692. Ini menunjukkan bahwa ada korelasi atau hubungan yang kuat antara variabel Budaya Organisasi (X1) dan Kompensasi (X2).

c. Variabel Budaya Organisasi (X1) dan Disiplin Kerja (X4) berhubungan atau berkorelasi dengan nilai koefisien korelasi sebesar 0,734. Ini menunjukkan bahwa ada korelasi atau hubungan yang kuat antara variabel Budaya Organisasi (X1) dan Disiplin Kerja (X4). d. Variabel Budaya Organisasi (X1) dan Motivasi (X5) berhubungan atau berkorelasi dengan nilai koefisien korelasi sebesar 0,698. Ini menunjukkan bahwa ada korelasi atau hubungan yang kuat antara variabel Budaya Organisasi (X1) dan Motivasi (X5).

e. Variabel Kompensasi (X2) dan Kepemimpinan (X3) berhubungan atau berkorelasi dengan nilai koefisien korelasi sebesar 0,669. Ini menunjukkan bahwa ada korelasi atau hubungan yang kuat antara variabel Kompensasi (X2) dan Kepemimpinan (X3).

f. Variabel Kompensasi (X2) dan Disiplin Kerja (X4) berhubungan atau berkorelasi dengan nilai koefisien korelasi sebesar 0,732. Ini menunjukkan bahwa ada korelasi atau hubungan yang kuat antara variabel Kompensasi (X2) dan Disiplin Kerja (X4).

g. Variabel Kompensasi (X2) dan Motivasi (X5) berhubungan atau berkorelasi dengan nilai koefisien korelasi sebesar 0,802. Ini menunjukkan bahwa ada korelasi atau hubungan yang sangat kuat antara variabel Kompensasi (X2) dan Motivasi (X5).

h. Variabel Kepemimpinan (X3) dan Disiplin Kerja (X4) berhubungan atau berkorelasi dengan nilai koefisien korelasi sebesar 0,777. Ini menunjukkan bahwa ada korelasi atau hubungan yang kuat antara variabel Kepemimpinan (X3) dan Disiplin Kerja (X4).

i. Variabel Kepemimpinan (X3) dan Produktivitas (X5) berhubungan atau berkorelasi dengan nilai koefisien korelasi sebesar 0,725. Ini menunjukkan bahwa ada korelasi atau hubungan yang kuat antara variabel Kepemimpinan (X3) dan Produktivitas (X5).

j. Variabel Disiplin Kerja (X4) dan Motivasi (X5) berhubungan atau berkorelasi dengan nilai koefisien korelasi 
sebesar 0,737. Ini menunjukkan bahwa ada korelasi atau hubungan yang kuat antara variabel Disiplin Kerja (X4) dan Motivasi (X5).

k. Variabel Budaya Organisasi (X1) terhadap Kepuasan Kerja (Y) memiliki koefisien regresi sebesar 0,363 dan signifikan dengan nilai $0,027<0,05$. Ini menunjukkan bahwa terdapat pengaruh yang rendah antara variabel Budaya Organisasi (X1) terhadap Kepuasan Kerja (Y).

1. Variabel Kompensasi (X2) terhadap Kepuasan Kerja (Y) memiliki koefisien regresi sebesar $-0,188$ dan tidak memenuhi syarat signifikan dengan nilai $0,294>0,05$. Ini menunjukkan bahwa terdapat pengaruh negatif yang sangat rendah antara variabel Kompensasi (X2) terhadap Kepuasan Kerja (Y).

m. Variabel Kepemimpinan (X3) terhadap Kepuasan Kerja (Y) memiliki koefisien regresi sebesar 0,347 dan signifikan dengan nilai $0,046<0,05$. Ini menunjukkan bahwa terdapat pengaruh yang rendah antara variabel Kepemimpinan (X1) terhadap Kepuasan Kerja (Y).

n. Variabel Disiplin Kerja (X4) terhadap Kepuasan Kerja (Y) memiliki koefisien regresi sebesar -0,042 dan tidak memenuhi syarat signifikan dengan nilai $0,821>0,05$. Ini menunjukkan bahwa terdapat pengaruh negatif yang sangat rendah antara variabel Disiplin Kerja (X4) terhadap Kepuasan Kerja (Y).

o. Variabel Motivasi (X5) terhadap Kepuasan Kerja (Y) memiliki koefisien regresi sebesar 0,473 dan signifikan dengan nilai $0,038<0,05$. Ini menunjukkan bahwa terdapat pengaruh yang rendah antara variabel Motivasi (X5) terhadap Kepuasan Kerja (Y).

p. Variabel Budaya Organisasi (X1), Kompensasi (X2), Kepemimpinan (X3), Disiplin Kerja (X4), dan Motivasi (X5) terhadap Kepuasan Kerja (Y) secara simultan memiliki koefisien regresi 0,661 dan signifikansi sebesar 0,000< 0,05. Ini Menunjukkan bahwa terdapat pengaruh yang kuat variabel Budaya Organisasi (X1), Kompensasi (X2), Kepemimpinan (X3), Disiplin Kerja (X4), dan Motivasi (X5) terhadap Kepuasan Kerja (Y). Terdapat 0,339 variabel lain yang mempengaruhi Kepuasan Kerja di yang tidak diteliti dalam penelitian ini.

q. Pengaruh tidak langsung variabel Budaya Organisasi (X1) melalui Kompensasi (X2) terhadap Kepuasan Kerja (Y) adalah $(0,363) \times(0,695) \times(-0,188)=-0,047$

r. Pengaruh tidak langsung variabel Budaya Organisasi (X1) melalui Kepemimpinan (X3) terhadap Kepuasan Kerja (Y) adalah $(0,363) \times(0,692) \times(0,347)=0,087$

s. Pengaruh tidak langsung variabel Budaya Organisasi (X1) melalui Disiplin Kerja (X4) terhadap Kepuasan Kerja (Y) adalah $(0,363) \times(0,734) \times(-0,042)=-0,011$

t. Pengaruh tidak langsung variabel Budaya Organisasi (X1) melalui Motivasi (X5) terhadap Kepuasan Kerja (Y) adalah $(0,363) \times(0,698) \times(0,473)=0,120$

u. Pengaruh tidak langsung variabel Kompensasi (X2) melalui Kepemimpinan (X3) terhadap Kepuasan Kerja (Y) adalah $(-0,188) \times(0,669) \times(0,347)=-0,044$

v. Pengaruh tidak langsung variabel Kompensasi (X2) melalui Disiplin Kerja (X4) terhadap Kepuasan Kerja (Y) adalah $(-0,188) \times(0,732) \times(-0,042)=0,006$

w. Pengaruh tidak langsung variabel Kompensasi (X2) melalui Motivasi (X5) terhadap Kepuasan Kerja (Y) adalah ($0,188) \times(0,802) \times(0,473)=0,071$

$\mathrm{x}$. Pengaruh tidak langsung variabel Kepemimpinan (X3) melalui Disiplin Kerja (X4) terhadap Kepuasan Kerja (Y) adalah $(0,347) \times(0,777) \times(-0,042)=-$ 0,011

y. Pengaruh tidak langsung variabel Kepemimpinan (X3) melalui Motivasi 
(X5) terhadap Kepuasan Kerja (Y) adalah $(0,347) \times(0,725) \times(0,473)=0,119$

z. Pengaruh tidak langsung variabel Disiplin Kerja (X4) melalui Motivasi (X5) terhadap Kepuasan Kerja (Y) adalah ($0,042) \times(0,737) \times(0,473)=-0,015$

aa. Variabel Budaya Organisasi (X1) terhadap Produktivitas (Z) memiliki koefisien regresi sebesar -0,284 dan tidak signifikan karena bernilai 0,222 > 0,05. Ini menunjukkan bahwa terdapat pengaruh secara negatif yang rendah antara variabel Budaya Organisasi (X1) terhadap Produktivitas (Z).

bb. Variabel Kompensasi (X2) terhadap Produktivitas (Z) memiliki koefisien regresi sebesar $-0,134$ dan tidak memenuhi syarat signifikan dengan nilai $0,584>0,05$. Ini menunjukkan bahwa terdapat pengaruh negatif yang sangat rendah antara variabel Kompensasi (X2) terhadap Produktivitas (Z).

cc. Variabel Kepemimpinan (X3) terhadap Produktivitas (Z) memiliki koefisien regresi sebesar $-0,416$ dan tidak memenuhi syarat signifikan dengan nilai $0,093>0,05$. Ini menunjukkan bahwa terdapat pengaruh negatif yang sedang antara variabel Kepemimpinan (X3) terhadap Produktivitas (Z).

dd. Variabel Disiplin Kerja (X4) terhadap Produktivitas (Z) memiliki koefisien regresi sebesar 0,468 dan tidak memenuhi syarat signifikan dengan nilai $0,067>$ 0,05 . Ini menunjukkan bahwa terdapat pengaruh yang sedang antara variabel Disiplin Kerja (X4) terhadap Produktivitas (Z).

ee. Variabel Motivasi (X5) terhadap Produktivitas (Z) memiliki koefisien regresi sebesar 0,489 dan tidak memenuhi syarat signifikan dengan nilai 0,074 > 0,05 . Ini menunjukkan bahwa terdapat pengaruh yang sedang antara variabel Motivasi (X5) terhadap Produktivitas (Z). ff. Variabel Kepuasan Kerja (Y) terhadap Produktivitas (Z) memiliki koefisien regresi sebesar 0,224 dan signifikan dengan nilai $0,002<0,05$. Ini menunjukkan bahwa terdapat pengaruh yang rendah antara variabel Kepuasan Kerja (Y) terhadap Produktivitas (Z). Terdapat 0,776 variabel lainnya yang mempengaruhi produktivitas diluar dari kepuasan kerja.

gg. Variabel Budaya Organisasi (X1), Kompensasi (X2), Kepemimpinan (X3), Disiplin Kerja (X4), dan Motivasi (X5) melalui Kepuasan Kerja (Y) terhadap Produktivitas (Z) memiliki koefisien regresi sebesar 0,394 dan signifikan dengan nilai 0,005 $<0,05$. Ini menunjukkan bahwa terdapat pengaruh yang rendah antara variabel Budaya Organisasi (X1), Kompensasi (X2), Kepemimpinan (X3), Disiplin Kerja (X4), dan Motivasi (X5) melalui Kepuasan Kerja (Y) terhadap Produktivitas (Z). Terdapat 0,606 variabel lain yang mempengaruhi produktivitas yang tidak diteliti dalam penelitian ini.

hh. Pengaruh tidak langsung variabel Budaya Organisasi (X1) melalui Kompensasi (X2) terhadap Produktivitas (Z) adalah $(-0,284)$ $\mathrm{x}(0,695) \times(-0,134)=0,026$

ii. Pengaruh tidak langsung variabel Budaya Organisasi (X1) melalui Kepemimpinan (X3) terhadap Produktivitas (Z) adalah ($0,284) \times(0,692) \times(-0,416)=0,082$

jj. Pengaruh tidak langsung variabel Budaya Organisasi (X1) melalui Disiplin Kerja (X4) terhadap Produktivitas (Z) adalah ($0,284) \times(0,734) \times(0,468)=0,098$

kk. Pengaruh tidak langsung variabel Budaya Organisasi (X1) melalui Motivasi (X5) terhadap Produktivitas $(\mathrm{Z})$ adalah $(-0,284)$ $x(0,698) \times(0,489)=-0,097$

ll. Pengaruh tidak langsung variabel Kompensasi (X2) melalui Kepemimpinan 
(X3) terhadap Produktivitas (Z) adalah ($0,134) \times(0,669) \times(-0,416)=0,037$

mm. Pengaruh tidak langsung variabel Kompensasi (X2) melalui Disiplin Kerja (X4) terhadap Produktivitas (Z) adalah ($0,134) \times(0,732) \times(-0,468)=0,046$

nn. Pengaruh tidak langsung variabel Kompensasi (X2) melalui Motivasi (X5) terhadap Produktivitas $(\mathrm{Z})$ adalah $(-0,134)$ $\mathrm{x}(0,802) \mathrm{x}(0,489)=0,053$

oo. Pengaruh tidak langsung variabel Kepemimpinan (X3) melalui Disiplin Kerja (X4) terhadap Produktivitas (Z) adalah $(-0,416) \times(0,777) \times(0,468)=-$ 0,151

pp. Pengaruh tidak langsung variabel Kepemimpinan (X3) melalui Motivasi (X5) terhadap Produktivitas (Z) adalah ($0,416) \times(0,725) \times(0,489)=-0,147$

qq. Pengaruh tidak langsung variabel Disiplin Kerja (X4) melalui Motivasi (X5) terhadap Produktivitas $(\mathrm{Z})$ adalah $(0,468)$ $\mathrm{x}(0,737) \mathrm{x}(0,489)=0,168$

\section{Pembahasan}

\section{Pengaruh Budaya Organisasi terhadap Kepuasan Kerja (Y)}

Variabel Budaya Organisasi

(X1)

terhadap Kepuasan Kerja (Y) Karyawan PT. Panairsan Pratama memiliki koefisien regresi sebesar 0,363 dan signifikan dengan nilai 0,027 < 0,05. Maka Ho ditolak dan Ha diterima karena terdapat pengaruh yang rendah antara variabel Budaya Organisasi (X1) terhadap Kepuasan Kerja (Y) pada karyawan PT. Panairsan Pratama. Hasil perhitungan ini menunjukkan adanya kesesuaian teori yang menyebutkan bahwa aspek dari kepuasan kerja yang diantaranya terdapat kemanan kerja, kondisi kerja, teman kerja, komunikasi dan beberapa aspek lainnya dimana aspek tersebut merupakan pengertian dari 7 elemen budaya organisasi yaitu stability dan collaboration oritentation. Hal hal yang memungkinkan rendahnya pengaruh budaya organisasi terhadap kepuasan kerja karyawan PT Panairsan adalah perusahaan ini masih kurang dalam memenuhi 7 elemen budaya organisasi. Sebagai contoh pada poin Inovasi, karyawan pada perusahaan ini sedikit enggan melakukan inovasi dan mengikuti komando dari pimpinan. Pada dasarnya seperti yang penulis sebutkan di latar belakang, bahwa PT. Panairsan Pratama meerupakan perusahaan keluarga dimana beberapa pengambil keputusan merupakan orang-orang penting yang merupakan bagian dari keluarga tersebut.

\section{Pengaruh Kompensasi (X2) terhadap Kepuasan Kerja (Y)}

Variabel Kompensasi (X2) terhadap Kepuasan Kerja (Y) karyawan PT. Panairsan Pratama memiliki koefisien regresi sebesar $-0,188$ dan tidak memenuhi syarat signifikan dengan nilai 0,294 > 0,05. Maka Ho ditolak dan Ha diterima karena terdapat pengaruh negatif yang sangat rendah antara variabel Kompensasi (X2) terhadap Kepuasan Kerja (Y) karyawan PT. Panairsan Pratama. Hasil ini sesuai dengan teori dimana Suwatno dan Priansa (2016:222) menyebutkan bahwa terdapat tujuan pemberian kompensasi, salah satunya adalah untuk kepuasan kerja. Namun pengaruh yang diberikan seharusnya bersifat positif. Mengapa hasil penelitian ini menunjukkan ada pengaruh yang negatif. Melalui observasi yang penulis lakukan, penulis menemukan bahwa pemberian kompensasi oleh perusahaan kepada karyawan nya berlandaskan asas like dan dislike akan prestasi karyawan tersebut yang pemilik perusahaan berikan. Dapat dikatakan bahwa pemberian kompensasi sedikit tidak sesuai dengan asas asas pemberian kompensasi yang sesuai dengan teori. 
3. Pengaruh Kepemimpinan

(X3) terhadap Kepuasan Kerja (Y)

Variabel Kepemimpinan (X3) terhadap Kepuasan Kerja (Y) karyawan PT. Panairsan Pratama memiliki koefisien regresi sebesar 0,347 dan signifikan dengan nilai $0,046<0,05$. Maka Ho di tolak dan Ha diterima. Ini menunjukkan bahwa terdapat pengaruh yang rendah antara variabel Kepemimpinan (X1) terhadap Kepuasan Kerja (Y) PT. Panairsan Pratama. Hasil penelitian ini menunjukkan kesesuaian dengan teori yang disebutkan oleh Sopiah dalam Hamali (2016:206) bahwa terdapat beberapa aspek kerja yang berpengaruh terhadap kepuasan kerja, dimana salah satu nya adalah administrasi/kebijakan perusahaan. Pada PT. Panairsan Pratama, pengambil kebijakan hanyalah pimpinan yang merupakan bagian dari keluarga pemilik perusahaan. Sehingga dapat disimpulkan terdapat kesesuaian antara teori dan hasil penelitian dilapangan.

4. Pengaruh Disiplin Kerja (X4) terhadap Kepuasan Kerja (Y)

Variabel Disiplin Kerja (X4) terhadap Kepuasan Kerja (Y) karyawan PT. Panairsan Pratama memiliki koefisien regresi sebesar $-0,042$ dan tidak memenuhi syarat signifikan dengan nilai 0,821 > 0,05. Maka Ho ditolak dan Ha diterima. Ini menunjukkan bahwa terdapat pengaruh negatif yang sangat rendah antara variabel Disiplin Kerja (X4) terhadap Kepuasan Kerja (Y) karyawan PT. Panairsan Pratama.

\section{Pengaruh Motivasi (X5) terhadap Kepuasan Kerja (Y) \\ Variabel Motivasi (X5) terhadap Kepuasan Kerja (Y) karyawan PT. Panairsan Pratama memiliki koefisien regresi sebesar 0,473 dan signifikan}

dengan nilai 0,038 < 0,05. Maka Ho ditolak dan Ha diterima. Ini menunjukkan bahwa terdapat pengaruh yang sedang antara variabel Motivasi (X5) terhadap Kepuasan Kerja (Y) karyawan PT. Panairsan Pratama. Hal ini sesuai dengan teori yang dituliskan oleh Sopiah dalam Hamali (2016:206) dimana aspek kerja yang berpengaruh terhadap kepuasan kerja adalah prestasi kerja, dimana menurut Luthans dalam Suwatno dan Priansa (2016-174) motivasi kerja berkenaan dengan salah satunya adalah kebutuhan untuk berprestasi. Meskipun terdapat heterogenitas yang cukup tinggi dalam tingkat pendidikan karyawan yang bekerja pada PT. Panairsan Pratama, namun semangat akan berprestasi cukup terlihat pada setiap individu.

6. Pengaruh Budaya Organisasi (X1), Kompensasi (X2), Kepemimpinan (X3), Disiplin Kerja (X4), dan Motivasi (X5) terhadap Kepuasan Kerja (Y).

Variabel Budaya Organisasi (X1) , Kompensasi (X2), Kepemimpinan (X3), Disiplin Kerja (X4), dan Motivasi (X5) secara bersama-sama (simultan) terhadap Kepuasan Kerja (Y) karyawan PT. Panairsan Pratama memiliki koefisien regresi sebesar 0,661 dan signifikan dengan nilai $0,000<0,05$. Maka Ho ditolak dan Ha diterima. Ini menunjukkan bahwa terdapat pengaruh yang kuat antara variabel Budaya Organisasi (X1) , Kompensasi (X2), Kepemimpinan (X3), Disiplin Kerja (X4), dan Motivasi (X5) secara bersamaan (simultan) terhadap Kepuasan Kerja (Y) karyawan PT. Panairsan Pratama.

7. Pengaruh Budaya Organisasi (X1) melalui Kompensasi (X2) terhadap Kepuasan Kerja (Y). 
Pengaruh tidak langsung variabel Budaya Organisasi (X1) melalui Kompensasi (X2) terhadap Kepuasan Kerja (Y) PT. Panairsan Pratama adalah $(0,363) \quad x$ $(0,695) \times(-0,188)=-0,047$. Maka Ho di tolak dan $\mathrm{Ha}$ diterima karena terdapat pengaruh negatif yang sangat rendah Budaya Organisasi (X1) melalui Kompensasi (X2) terhadap Kepuasan Kerja (Y) karyawan PT. Panairsan Pratama.

8. Pengaruh Budaya Organisasi (X1) melalui Kepemimpinan (X3) terhadap Kepuasan Kerja (Y).

Pengaruh tidak langsung variabel Budaya Organisasi (X1) melalui Kepemimpinan (X3) terhadap Kepuasan Kerja (Y) PT. Panairsan Pratama adalah (0,363) x $(0,692) \times(0,347)=0,087$ Maka Ho di tolak dan Ha diterima karena terdapat pengaruh yang sangat rendah Budaya Organisasi (X1) melalui Kepemimpinan (X3) terhadap Kepuasan Kerja (Y) karyawan PT. Panairsan Pratama.

9. Pengaruh Budaya Organisasi (X1) melalui Disiplin Kerja (X4) terhadap Kepuasan Kerja (Y).

Pengaruh tidak langsung variabel Budaya Organisasi (X1) melalui Disiplin Kerja (X4) terhadap Kepuasan Kerja (Y) PT. Panairsan Pratama adalah $(0,363) \quad x$ $(0,734) \times(-0,042)=-0,011$. Maka Ho di tolak dan Ha diterima karena terdapat pengaruh negatif yang sangat rendah Budaya Organisasi (X1) melalui Disiplin Kerja (X4) terhadap Kepuasan Kerja (Y) karyawan PT. Panairsan Pratama.

10. Pengaruh Budaya Organisasi (X1) melalui Motivasi (X5) terhadap Kepuasan Kerja (Y).

Pengaruh tidak langsung variabel Budaya Organisasi (X1) melalui Motivasi (X5) terhadap Kepuasan Kerja (Y) PT.
Panairsan Pratama adalah (0,363) x $(0,698) \times(0,473)=0,120$. Maka Ho di tolak dan Ha diterima karena terdapat pengaruh yang sangat rendah Budaya Organisasi (X1) melalui Motivasi (X5) terhadap Kepuasan Kerja (Y) karyawan PT. Panairsan Pratama.

11. Pengaruh Kompensasi (X2) melalui Kepemimpinan (X3) terhadap Kepuasan Kerja (Y).

Pengaruh tidak langsung variabel Kompensasi (X2) melalui Kepemimpinan (X3) terhadap Kepuasan Kerja (Y) karyawan PT. Panairsan Pratama adalah ($0,188) \times(0,669) \times(0,347)=-0,044$. Maka Ho ditolak dan Ha diterima karena tedapat pengaruh negatif yang sangat rendah variabel Kompensasi (X2) melalui Kepemimpinan (X3) terhadap Kepuasan Kerja (Y) karyawan PT. Panairsan Pratama.

12. Pengaruh Kompensasi (X2) melalui Disiplin Kerja (X4) terhadap Kepuasan Kerja (Y).

Pengaruh tidak langsung variabel Kompensasi (X2) melalui Disiplin Kerja (X4) terhadap Kepuasan Kerja (Y) karyawan PT. Panairsan Pratama adalah ($0,188) \times(0,732) \times(-0,042)=0,006$. Maka Ho ditolak dan Ha diterima karena tedapat pengaruh yang sangat rendah variabel Kompensasi (X2) melalui Disiplin Kerja (X4) terhadap Kepuasan Kerja (Y) karyawan PT. Panairsan Pratama.

13. Pengaruh Kompensasi (X2) melalui Motivasi (X5) terhadap Kepuasan Kerja (Y).

Pengaruh tidak langsung variabel Kompensasi (X2) melalui Motivasi (X5) terhadap Kepuasan Kerja (Y) karyawan PT. Panairsan Pratama adalah $(-0,188) \mathrm{x}$ $(0,802) \times(0,473)=0,071$. Maka Ho ditolak dan Ha diterima karena tedapat 
pengaruh yang sangat rendah variabel Kompensasi (X2) melalui Motivasi (X5) terhadap Kepuasan Kerja (Y) karyawan PT. Panairsan Pratama.

14. Pengaruh Kepemimpinan (X3) melalui Disiplin Kerja (X4) terhadap Kepuasan Kerja (Y).

Pengaruh tidak langsung variabel Kepemimpinan (X3) melalui Disiplin Kerja (X4) terhadap Kepuasan Kerja (Y) karyawan PT. Panairsan Pratama adalah $(0,347) \times(0,777) \times(-0,042)=-0,011$. Maka Ho ditolak dan Ha diterima karena tedapat pengaruh negatif yang sangat rendah variabel Kepemimpinan (X3) melalui Disiplin Kerja (X4) terhadap Kepuasan Kerja (Y) karyawan PT. Panairsan Pratama.

\section{Pengaruh Kepemimpinan (X3) melalui} Motivasi (X5) terhadap Kepuasan Kerja (Y).

Pengaruh tidak langsung variabel Kepemimpinan (X3) melalui Motivasi (X5) terhadap Kepuasan Kerja (Y) karyawan PT. Panairsan Pratama adalah $(0,347) \times(0,725) \times(0,473)=0,119$. Maka Ho ditolak dan Ha diterima karena tedapat pengaruh yang sangat rendah variabel Kepemimpinan (X3) melalui Motivasi (X5) terhadap Kepuasan Kerja (Y) karyawan PT. Panairsan Pratama.

\section{Pengaruh Disiplin Kerja (X4) melalui Motivasi (X5) terhadap Kepuasan Kerja (Y).}

Pengaruh tidak langsung variabel Disiplin Kerja (X4) melalui Motivasi (X5) terhadap Kepuasan Kerja (Y) karyawan PT. Panairsan Pratama adalah $(-0,042) \mathrm{x}$ $(0,737) \times(0,473)=-0,015$. Maka Ho ditolak dan Ha diterima karena tedapat pengaruh negatif yang sangat rendah variabel Disiplin Kerja (X4) melalui Motivasi (X5) terhadap Kepuasan Kerja (Y) karyawan PT. Panairsan Pratama.

\section{Pengaruh Kepuasan Kerja (Y)} terhadap Produktivitas (Z).

Pengaruh variabel Kepuasan Kerja (Y) terhadap Produktivitas (Z) karyawan PT. Panairsan Pratama memiliki koefisien regresi sebesar 0,224 dan signifikan dengan nilai $0,002<0,05$. Maka Ho ditolak dan Ha diterima. Ini menunjukkan bahwa terdapat pengaruh yang rendah antara variabel Kepuasan Kerja (Y) terhadap Produktivitas (Z) karyawan PT. Panairsan Pratama. Ardana, Mujiati dan Utama (2012:270) telah menyebutkan bahwa beberapa hal yang dapat dijadikan sumber informasi untuk menilai produktivitas adalah kepuasan kerja. Hal ini menunjukkan kesesuian teori dengan hasil penelitian pada PT Panairsan Pratama.

\section{Pengaruh Budaya Organisasi terhadap Produktivitas (Z)}

(X1) Pengaruh variabel Budaya Organisasi (X1) terhadap Produktivitas (Z) karyawan PT. Panairsan Pratama memiliki koefisien regresi sebesar -0,284 dan tidak signifikan karena bernilai 0,222 >0,05. Maka Ho ditolak dan Ha diterima karena terdapat pengaruh secara negatif yang rendah antara variabel Budaya Organisasi (X1) terhadap Produktivitas (Z) karyawan PT. Panairsan Pratama. Dalam 7 elemen budaya organisasi Wibowo (2016:32) menyebutkan bahwa salah satu elemen tersebut adalah Easygoing atau bersikap tenang dimana tercipta iklim kerja bersifat santai. PT. Panairsan tidak menerapkan hal tersebut. Tensi yang tinggi dalam mendorong produktivitas. Hal ini yang memungkinkan terjadi nya nilai negatif budaya organisasi kepada produktivitas. 


\section{Pengaruh Kompensasi (X2) terhadap Produktivitas (Z)}

Pengaruh variabel Kompensasi (X2) terhadap Produktivitas (Z) karyawan PT. Panairsan Pratama memiliki koefisien regresi sebesar -0,134 dan tidak signifikan karena bernilai 0,584 >0,05. Maka Ho ditolak dan Ha diterima karena terdapat pengaruh secara negatif yang sangat rendah antara variabel Kompensasi (X2) terhadap Produktivitas (Z) karyawan PT. Panairsan Pratama. Seharusnya kompensasi yang layak akan memberikan rangsangan serta memotivasi karyawan untuk memberikan produktivitas kerja yang optimal, Suwatno dan Priansa (2016:222). Namun yang terjadi dalam penelitian tidaklah seperti itu. PT. Panairsan Pratama melakukan pemberian kompensasi yang berbeda-beda kepada karyawannya meskipun karyawan tersebut bekerja di bagian atau departemen yang sama, dimana semua keputusan akan pemberian kompensasi ini sepenuhnya ditentukan oleh pimpinan.

\section{Pengaruh Kepemimpinan terhadap Produktivitas (Z)}

(X3)

Pengaruh variabel Kepemimpinan (X3) terhadap Produktivitas (Z) karyawan PT. Panairsan Pratama memiliki koefisien regresi sebesar -0,416 dan tidak signifikan karena bernilai 0,093 >0,05. Maka Ho ditolak dan Ha diterima karena terdapat pengaruh secara negatif yang sedang antara variabel Kepemimpinan (X3) terhadap Produktivitas (Z) karyawan PT. Panairsan Pratama. Pimpinan pada perusahaan ini banyak menerapkan metode kepemimpinan menurut Ordweay yaitu memberikan perintah dan memberikan celaan dan pujian. Hal ini memungkinkan bahwa kepemimpinan yang di terapkan berpengaruh secara negatif terhadap produktivitas.

\section{Pengaruh Disiplin Kerja (X4) terhadap} Produktivitas (Z)

Pengaruh variabel Disiplin Kerja (X4) terhadap Produktivitas (Z) karyawan PT. Panairsan Pratama memiliki koefisien regresi sebesar 0,468 dan tidak memenuhi syarat signifikan karena bernilai 0,067 > 0,05. Maka Ho ditolak dan Ha diterima karena terdapat pengaruh yang sedang antara variabel Disiplin Kerja (X4) terhadap Produktivitas (Z) karyawan PT. Panairsan Pratama. Hal ini menunjukkan kesesuaian teori Sutrisno dalam Hamali (2016:215) bahwa disiplin yang baik akan tercermin pada suasana meningkatnya produktivitas kerja karyawan.

22. Pengaruh Motivasi (X5) terhadap Produktivitas (Z)

Pengaruh variabel Motivasi (X5) terhadap Produktivitas (Z) karyawan PT. Panairsan Pratama memiliki koefisien regresi sebesar 0,489 dan tidak signifikan karena bernilai 0,074 > 0,05. Maka Ho ditolak dan Ha diterima karena terdapat pengaruh yang sedang antara variabel Motivasi (X5) terhadap Produktivitas (Z) karyawan PT. Panairsan Pratama. Hal ini sesuai dengan Luthans dalam Suwatno (2016:174) yaitu motivasi akan berkenaan dengan melakukan sesuatu yang lebih baik dari pesaing, menyelesaikan tugas, dan berbagai hal lain yang berkenaan dengan produktivitas.

23. Pengaruh Budaya Organisasi (X1), Kompensasi (X2), Kepemimpinan (X3), Disiplin Kerja (X4), dan Motivasi (X5) melalui Kepuasan Kerja (Y) terhadap Produktivitas (Z).

Pengaruh variabel Budaya Organisasi (X1), Kompensasi (X2), Kepemimpinan (X3), Disiplin Kerja (X4), dan Motivasi (X5) melalui Kepuasan Kerja (Y) terhadap Produktivitas (Z) karyawan PT. 
Panairsan Pratama memiliki koefisien regresi sebesar 0,394 dan signifikan dengan nilai $0,005<0,05$. Maka Ho ditolak dan Ha diterima. Hal ini menunjukkan bahwa terdapat pengaruh yang rendah antara variabel Budaya Organisasi (X1), Kompensasi (X2), Kepemimpinan (X3), Disiplin Kerja (X4), dan Motivasi (X5) melalui Kepuasan Kerja (Y) terhadap Produktivitas (Z) pada karyawan PT. Panairsan Pratama.

24. Pengaruh Budaya Organisasi (X1) melalui Kompensasi (X2) terhadap Produktivitas (Z)

Pengaruh tidak langsung variabel Budaya Organisasi (X1) melalui Kompensasi (X2) terhadap Produktivitas (Z) PT. Panairsan Pratama adalah $(-0,284) \times(0,695) \times(-$ $0,134)=0,026$. Maka Ho di tolak dan Ha diterima karena terdapat pengaruh yang sangat rendah Budaya Organisasi (X1) melalui Kompensasi (X2) terhadap Produktivitas (Z) karyawan PT. Panairsan Pratama.

25. Pengaruh Budaya Organisasi (X1) melalui Kepemimpinan (X3) terhadap Produktivitas (Z)

Pengaruh tidak langsung variabel Budaya Organisasi (X1) melalui Kepemimpinan (X3) terhadap Produktivitas (Z) PT. Panairsan Pratama adalah $(-0,284) \quad x$ $(0,692) \times(-0,416)=0,082$. Maka Ho di tolak dan $\mathrm{Ha}$ diterima karena terdapat pengaruh yang sangat rendah Budaya Organisasi (X1) melalui Kepemimpinan (X3) terhadap Produktivitas (Z) karyawan PT. Panairsan Pratama.

26. Pengaruh Budaya Organisasi (X1) melalui Disiplin Kerja (X4) terhadap Produktivitas (Z)

Pengaruh tidak langsung variabel Budaya Organisasi (X1) melalui Disiplin Kerja
(X4) terhadap Produktivitas (Z) PT. Panairsan Pratama adalah $(-0,284) \quad x$ $(0,734) \times(0,468)=0,098$. Maka Ho di tolak dan $\mathrm{Ha}$ diterima karena terdapat pengaruh yang sangat rendah Budaya Organisasi (X1) melalui Disiplin Kerja (X4) terhadap Produktivitas (Z) karyawan PT. Panairsan Pratama.

27. Pengaruh Budaya Organisasi (X1) melalui Motivasi (X5) terhadap Produktivitas (Z)

Pengaruh tidak langsung variabel Budaya Organisasi (X1) melalui Motivasi (X5) terhadap Produktivitas (Z) PT. Panairsan Pratama adalah $(-0,284) \quad x \quad(0,698) \quad x$ $(0,489)=-0,097$. Maka Ho di tolak dan Ha diterima karena terdapat pengaruh negatif yang sangat rendah Budaya Organisasi (X1) melalui Motivasi (X5) terhadap Produktivitas (Z) karyawan PT. Panairsan Pratama.

28. Pengaruh Kompensasi (X2) melalui Kepemimpinan Produktivitas (Z)

(X3) terhadap Pengaruh tidak langsung variabel Kompensasi (X2) melalui Kepemimpinan (X3) terhadap Produktivitas (Z) PT. Panairsan Pratama adalah $(-0,134) \quad x$ $(0,669) \times(-0,416)=0,037$. Maka Ho di tolak dan Ha diterima karena terdapat pengaruh yang sangat rendah Kompensasi (X2) melalui Kepemimpinan (X3) terhadap Produktivitas (Z) karyawan PT. Panairsan Pratama.

29. Pengaruh Kompensasi (X2) melalui Disiplin Kerja (X4) terhadap Produktivitas (Z)

Pengaruh tidak langsung variabel Kompensasi (X2) melalui Disiplin Kerja (X4) terhadap Produktivitas (Z) PT. Panairsan Pratama adalah $(-0,134)$ x $(0,732) \times(-0,468)=0,046$. Maka Ho di 
tolak dan Ha diterima karena terdapat pengaruh yang sangat rendah Kompensasi (X2) melalui Disiplin Kerja (X4) terhadap Produktivitas (Z) karyawan PT. Panairsan Pratama.

\section{Pengaruh Kompensasi (X2) melalui Motivasi (X5) terhadap Produktivitas (Z)}

Pengaruh tidak langsung variabel Kompensasi (X2) melalui Motivasi (X5) terhadap Produktivitas (Z) PT. Panairsan Pratama adalah $(-0,134)$ X $(0,802) \times$ $(0,489)=0,053$. Maka Ho di tolak dan $\mathrm{Ha}$ diterima karena terdapat pengaruh yang sangat rendah Kompensasi (X2) melalui Motivasi (X5) terhadap Produktivitas (Z) karyawan PT. Panairsan Pratama.

\section{Pengaruh Kepemimpinan (X3) melalui Disiplin Kerja (X4) terhadap Produktivitas (Z)}

Pengaruh tidak langsung variabel Kepemimpinan (X3) melalui Disiplin Kerja (X4) terhadap Produktivitas (Z) PT. Panairsan Pratama adalah $(-0,416) \quad x$ $(0,777) \times(0,468)=-0,151$. Maka Ho di tolak dan Ha diterima karena terdapat pengaruh negatif yang sangat rendah Kepemimpinan (X3) melalui Disiplin Kerja (X4) terhadap Produktivitas (Z) karyawan PT. Panairsan Pratama.

\section{Pengaruh Kepemimpinan (X3) melalui} Motivasi (X5) terhadap Produktivitas (Z)

Pengaruh tidak langsung variabel Kepemimpinan (X3) melalui Motivasi (X5) terhadap Produktivitas (Z) PT. Panairsan Pratama adalah $(-0,416) \quad x$ $(0,725) \times(0,489)=-0,147$. Maka Ho di tolak dan Ha diterima karena terdapat pengaruh negatif yang sangat rendah Kepemimpinan (X3) melalui Motivasi (X5) terhadap Produktivitas (Z) karyawan PT. Panairsan Pratama.

\section{Pengaruh Disiplin Kerja (X4) melalui Motivasi (X5) terhadap Produktivitas (Z)}

Pengaruh tidak langsung variabel Disiplin Kerja (X4) melalui Motivasi (X5) terhadap Produktivitas (Z) PT. Panairsan Pratama adalah $(0,468) \quad x \quad(0,737) \quad x$ $(0,489)=0,168$. Maka Ho di tolak dan Ha diterima karena terdapat pengaruh yang sangat rendah Disiplin Kerja (X4) melalui Motivasi (X5) terhadap Produktivitas (Z) karyawan PT. Panairsan Pratama.

\section{KESIMPULAN DAN SARAN \\ Kesimpulan}

Berdasarkan hasil penelitian tentang budaya organisasi, kompensasi, kepemimpinan, disiplin kerja dan motivasi berpengaruh terhadap kepuasan kerja dan berdampak kepada produktivitas karyawan PT. Panairsan Pratama, maka diperoleh kesimpulan sebagai berikut :

1. Budaya organisasi, kompensasi, kepemimpinan, disiplin kerja dan motivasi berpengaruh dan signifikan terhadap kepuasan kerja karyawan pada PT. Panairsan Pratama dimana motivasi merupakan variabel yang dominan dalam mempengaruhi kepuasan kerja.

2. Kepuasan kerja berpengaruh rendah dan signifikan terhadap produktivitas karyawan pada PT. Panairsan Pratama.

3. Budaya organisasi, kompensasi, kepemimpinan, disiplin kerja, motivasi dan kepuasan kerja berpengaruh dan signifikan terhadap produktivitas karyawan pada PT. Panairsan Pratama.

\section{Saran}

Berdasarkan hasil penelitian dan keterbatasan penulis , maka saran yang diberikan adalah sebagai berikut :

1. Untuk meningkatkan kepuasan kerja dan produktivitas karyawan PT. Panairsan Pratama maka perlu dilakukan pelatihan- 
pelatihan serta memfasilitasi karyawan dengan program bantuan pendidikan agar karyawan PT. Panairsan Pratama dapat meningkatkan wawasan dan pengetahuannya melalui pendidikan dan pelatihan.

2. Dalam mengola sumber daya manusia nya PT. Panairsan Pratama sebaiknya mencoba untuk beralih dari sistem kekeluargaan dan melirik ke arah pengelolaan sumber daya manusia yang modern, professional dan sistematis.

3. Pemberian kompensasi kepada karyawan, ada baiknya perusahaan mulai menggunakan asas profesionalisme dan memperhatikan ketentuan-ketentuan yang ditetapkan oleh pemerintah.

4. PT. Panairsan Pratama sebaiknya menerapkan sistem reward dan punishment kepada karyawannya dalam rangka meningkatkan disiplin kerja karyawan.

5. Penelitian ini merupakan penelitian dengan pendekatan kuantitatif yang menggunakan kuesioner sebagai teknik pengumpulan data, dimana responden melakukan pengisian kuisioner sebagai data yang akan dianalisis. Hasil yang dipaparkan penelitian ini tidak dilengkapi dengan analisis kualitatif. Untuk mendapatkan hasil yang lebih baik diharapkan penelitian lanjutan menggunakan pendekatan kualitatif dan kuantitatif seperti menggunakan teknik wawancara sehingga maksud responden dapat ditangkap dengan sempurna.

\section{DAFTAR PUSTAKA}

Ardana, I Komang, Ni WayanMujiati, I WayanMudiarthaUtama. 2012. Manajemen Sumber Daya Manusia. GRAHA ILMU. Yogyakarta.

Arditi, David, Shruti Nayak dan Atilla Damci. (2017). Effect of Organisational
Culture on Delay in Construction. International Journal of Project Management, 35, 136-147.

Becchetti, Leonardo, Stefano Castriota dan Ermanno C. Tortia. (2013). Productivity, wages and intrinsic motivations. Small Business Economics, 41(2), 379-399.

Ghozali, Imam danFuad. 2014. Structural Equation Modeling Teori, Konsep dan Aplikasi dengan Program. BadanPenerbit-Undip. Semarang.

Hamali, Arif Yusuf. 2016. Pemahaman Manajemen Sumber Daya Manusia Strategi Mengelola Karyawan. CAPS (Center For Academic Publishing Service. Yogyakarta.

Heinz, Marcel. 2014. Systematic Mapping Studies.

Heryanto, Imam dan Totok Triwibowo. 2018. Path Analysis Menggunakan SPSS Dan Excel. Informatika Bandung. Bandung.

https://www.liputan6.com/bisnis/read/515579/

7-plus-7-isu-yang-mesti-dihadapiperusahaan-keluarga

https://www.scopus.com/home.uri

https://www.sciencedirect.com/

https://scholar.google.co.id/

http://e-resources.perpusnas.go.id/

https://journals.aom.org/doi/abs/10.5465/2015 $\underline{9587}$

http://ajpssi.org/index.php/ajpssi/article/view/ $\underline{223}$

https://onlinelibrary.wiley.com/doi/abs/10.111 1/j.1467-9299.2012.02108.x

http://journals.sagepub.com/doi/abs/10.1177/2 $\underline{329488414525453}$

Janssen, One dan Nico W. Van Yperen. ( 2017). Employees' Goal Orientation, the Quality of Leader Member Exchange, and the Outcomes of Job Performances and Job Satisfaction. Academy of Management Journal, 47(3). 
M, Ajala E. (2017). A Relationship Study Between Organisational Justice And Job Satisfaction Among Industrial Employees In Ogun State, Nigeria. African Journal For Psycological Studies of Social Issues, 20(2).

Nawab, Dr. Samina dan Komal Khalid Bhatti. (2018). Influence of Employee Compensation on Organizational Commitment and Job Satisfaction: A Case Study of Educational Sector of Pakistan. International Journal of Business and Social Science, 2(8).

Pettersen, Kai, Robert Feld, ShahidMujtaba, Michael Mattsson. Systematic Mapping Studies in Software Engineering.

Priyatno, Duwi. 2017. Panduan Praktis Olah Data Menggunakan SPSS. CVANDI OFFSET. Yogyakarta.

Raina, Reeta dan Deborah Britt Roebuck. (2014). Exploring Cultural Influence on Managerial Communication in Relationship to Job Satisfaction, Organisational Commitment, and Employees' Propensity to Leave in the Insurance Sector of India. International Journal of Business Communication, 55(3), 97-130.

Rauf, Ismet. 2015. Lintas "Majalah Infrastruktur \& Transportasi”. Edisi 38/Tahun VII/Mei-Juni 2015. Koperasi Primer Bina Marga. Jakarta.

Riadi, Edi. 2016. Statistika Penelitian (Analisis Manual dan IBM SPSS). CV ANDI OFFSET. Yogyakarta.

Sunyoto, Danang. 2013. Manajemen Sumber Daya Manusia. CAPS (Center For Academic Publishing Service. Yogyakarta.

Suwatno dan Priansa, Donni Juni. 2016. Manajemen SDM dalam Organisasi Publik dan Bisnis. ALFABETA. Bandung.
Sugiyono. 2012. Metode Penelitian Kuantitatif Kualitatif dan R\&D. Alfabeta Bandung.

Sugiyono. 2014. Metode Penelitian Manajemen. Alfabeta. Bandung

Taylor, Jeannette. (2014). Public Service Motivation, Relational Job Design, And Job Satisfaction In Local Government. Symposium : The Future of Public Service Motivation Research. Edited by Wouter Vandenabeele, Gene Brewer and Adrian Ritz. 92(4), 902918.

Wibowo. 2016. Budaya Organisasi Sebuah Kebutuhan untuk Meningkatkan Kinerja Jangka Panjang. EdisiKedua. PT.RAJAGRAFINDO PERSADA. Jakarta.

Yamoah dan Emmanuel Erastus. (2013). Relationship between Compensation and Employee Productivity. Singaporean Journal of Business, Economics and Management Studies, 2(1), 104-114. 